Estuarine, Coastal and Shelf Science

November 2018, Volume 212, Pages 164-175

http://dx.doi.org/10.1016/i.ecss.2018.07.007

http://archimer.ifremer.fr/doc/00449/56052/

(c) 2018 Elsevier Ltd. All rights reserved.

\title{
Distribution, associated species and extent of biofouling "reefs" formed by the alien species Ficopomatus enigmaticus (Annelida, Polychaeta) in marinas
}

\author{
Charles Maud ${ }^{1,2}$, Faillettaz Robin ${ }^{3}$, Desroy Nicolas ${ }^{4}$, Fournier Jérome ${ }^{5,6}$, Costil Katherine ${ }^{1,2,{ }^{*}}$
}

\author{
${ }^{1}$ Normandie Université, F-14032, Caen, France \\ 2 UMR BOREA (Biologie des Organismes et Ecosystèmes Aquatiques), MNHN, UPMC, UCN, CNRS- \\ 7208, IRD-207, Université de Caen Normandie, Esplanade de la Paix, 14032, Caen Cedex 5, France \\ ${ }^{3}$ Sorbonne Université, UPMC Université de Paris 06, CNRS, Laboratoire d'Océanographie de \\ Villefranche (LOV), Villefranche-sur-Mer, France \\ ${ }^{4}$ IFREMER, Laboratoire Environment et Resources Bretagne Nord, 38 rue du Port Blanc, BP 80108, \\ 35801, Dinard cedex, France \\ ${ }^{5}$ CNRS, UMR 7208 BOREA, 61 rue Buffon, CP 53, 75231, Paris cedex 05, France \\ ${ }^{6}$ MNHN, Station de Biologie Marine, BP 225, 29182, Concarneau cedex, France \\ * Corresponding author : Katherine Costil, email address : katherine.costil@unicaen.fr
}

\begin{abstract}
:
Artificial structures in ports are commonly colonized by non-indigenous epifauna that tolerate high pollution levels. Bioconstructions built by alien species may offer sheltered microhabitats for motile (vagile) animals but biofouling often becomes detrimental to human activities. In this context, the present study provides an inventory of 1) the extent of biofouling related to the alien Polychaeta Ficopomatus enigmaticus on hard structures of marinas in Normandy, France, and 2) the biodiversity of sessile (attached) or vagile (motile) fauna associated with these "reefs", including both native and alien species. Reefs built by $F$. enigmaticus were found in 6 out of 12 marinas with oligohaline-mesohaline waters. Significant differences in the total volume of biofouling were found among sites, with maximum values observed in Honfleur's old basin $\left(459.52 \mathrm{~mL}\right.$ per $\left.0.04 \mathrm{~m}^{2}\right)$. Ficopomatus enigmaticus greatly dominated the sessile invertebrate community both in volume $(74-100 \%)$ and weight $(70-100 \%)$ in 5 out of 6 marinas. The fouling formed by 5 alien species was colonized by 15 motile invertebrate taxa, including 3 cryptogenic or alien species. The alien crab Rhithropanopeus harrisi displayed the highest frequency of occurrence $(>80 \%)$ and mean density $\left(>300\right.$ ind $\left.\mathrm{m}^{-2}\right)$, and the global densities of sessile (except $F$. enigmaticus) and motile fauna were significantly correlated $(r=0.824 ; p<0.05)$. While motile fauna density was also significantly correlated with the biovolume of $B$. improvisus and $M$. leucophaeata, it was not with $F$. enigmaticus $(r=0.421 ; p>0.05)$. In line with previous studies, these results suggest that $F$. enigmaticus acts as an engineer offering shelter for reef-associated organisms. In addition, results suggest that at the regional scale, inter-site differences in motile fauna may reflect differences in environmental parameters such as salinity. The presence of $F$. enigmaticus at low salinity levels led to assess its potential distribution at the scale of the European coasts, suggesting that in the context of climate change, favorable conditions for spawning $\left(>18^{\circ} \mathrm{C}\right)$ will likely expand towards the North, and particularly in the eastern and northern Baltic Sea.
\end{abstract}




\section{Highlights}

- Biofouling in Normandy's marinas (France) was dominated by Ficopomatus enigmaticus. Reefs built by $F$. enigmaticus were colonized by 4 sessile and 15 motile taxa. 7 ( 4 sessile, 3 motile) out of the 17 species identified were alien. The density of motile fauna was not correlated with the volume of $F$. enigmaticus. The crab Rhithropanopeus harrisi showed the highest frequency and mean density.

Keywords: Biofouling, Ficopomatus enigmaticus, Benthic communities, Alien species, Marinas, Normandy (France) 


\section{Introduction}

Due to wide fluctuations in environmental conditions, brackish habitats are populated by few benthic and pelagic species (McLusky and Elliott, 2004), (e.g. Pérez-Ruzafa et al., 2005; Freire et al., 2012). However, these demanding environments generally show high primary production (e.g. 
Justic et al., 1995), and support abundant filter-feeding populations. The construction of ports and marinas locally disrupts coastal hydrodynamics through the excavation of channels and construction of artificial structures, which may affect the supply and settlement of planktonic propagules in surrounding habitats (Eckman, 1983; Floert, 2005). Marinas and ports also offer sheltered habitats for species that require low hydrodynamics. Nevertheless, port environments are characterized by various contaminants which may cause stress to aquatic organisms (e.g. de los Ríos et al., 2016). Ports and marinas are therefore colonized by species with high resistance to pollution and broad ecological amplitude.

The epifauna that colonize artificial structures in ports are often dominated by non-indigenous species (Glasby et al., 2007). Ports generally facilitates aquatic invasions because of the constant entrance of alien biota carried by ships, and their degraded environment (Floert, 2005; Molnar et al., 2008; Seebens et al., 2013). Molnar et al. (2008) classified the English Channel among the coastal ecoregions particularly affected by harmful alien species (31-56 species). In the port of Le Havre, the main commercial port in the region (Fig. 1), the proportion of introduced animal species currently reaches $9.9 \%$ (36 species), among which 5.2\% are ancient introductions (prior to 1970), and 4.7\% are recent ones (later than 1970) (Breton, 2014). The Australian tubeworm, Ficopomatus enigmaticus (Fauvel, 1923), formerly Mercierella enigmatica, may not have been introduced in Europe from Le Havre, as it was first observed in 1921 by Fauvel in Caen's canal that connects Caen to the English Channel (Fauvel, 1923). A year later, in 1922, it was observed on the docks in London (Eno et al., 1997; Dewarumez et al., 2011). Today, F. enigmaticus has established populations worldwide (ten Hove and Weerdenburg, 1978; ISSG, 2018). Fauvel (1923) also recorded the presence of dark false mussels Mytilopsis leucophaeata (formerly known as Congeria cochleria) for the first time in France and in the same canal. The species, prior to this observation, was mostly distributed in subtropical and warm-temperate regions (Zhulidov et al., 2015). To our knowledge, no additional observations have been made in our region since these first records, while the presence of both $F$. enigmaticus and M. leucophaeata has been reported in several European countries, from the Mediterranean basin to Scandinavian countries (e.g. Fornos et al., 1997; Zhulidov et al., 2015; DAISIE, 2018; ISSG, 2018).

Introduced species should be under close surveillance since invasions by exotic species are one of the main causes of recent declines in biodiversity, notably in aquatic environments that are especially susceptible to invasions (Dunham et al., 2002). Moreover, non-native sessile (attached) species that build reef structures and species with shelf or hard exoskeleton can form biofouling on hard substrates such as port structures or boat hulls. The development of fouling assemblages is regulated by a complex process involving biochemical, physical and ecological factors (Craig et al., 
2001; Floert, 2005). Ficopomatus enigmaticus ("EUNIS habitat code": A5.529; INPN, 2018a), which has been reported to be a very effective invader, builds calcareous tubes that can form extensive biofouling and may induce significant nuisances for human activities (e.g. shipping; Fornos et al., 1997; ISSG, 2018). In Europe, other alien species like M. leucophaeata and barnacles (i.e. Balanus improvisus and B. amphitrite) cause fouling problems and may even cause malfunction in industrial cooling water systems (ISSG, 2018, Verween et al., 2010; Kennedy, 2011). Fouling organisms may also lead to ecological disturbances, since "reefs" built by $F$. enigmaticus generate topographic heterogeneity that can modify water movements and sediment transport, particularly in the estuarine environments where reefs are well developed (e.g. Swindt et al., 2004). Like other serpulid species, the Australian tubeworm is a filter-feeder, feeding on suspended detritus and phytoplankton (Davies et al., 1989). It is capable of decreasing water turbidity and may induce food depletion (Bruschetti et al., 2008). In addition, this worm can change macroalgal composition and abundance by excluding some species and hosting others (Bazterrica et al., 2013). Joyce et al. (2005) and McQuaid and Griffiths (2014) highlighted a positive correlation between $F$. enigmaticus reef mass and infaunal biomass, suggesting that $F$. enigmaticus has a significant impact on sympatric benthic species. Finally, Bruschetti et al. (2009) have reported a potential positive effect on shorebirds with a higher availability of epifaunal prey that positively affected the birds' foraging rates in an Argentinian coastal lagoon.

Brackish environments such as coastal lagoons, estuaries, ports and marinas are characterized by wide fluctuations in abiotic factors resulting in major biological changes, including changes in benthic assemblages at various spatial scales (Pérez-Ruzafa et al., 2005; Morais et al., 2016). While diachronic studies conducted over long periods are necessary to take into account these fluctuations, synchronic studies provide a snapshot of the faunal communities inhabiting different sites. This second approach was chosen for this exploratory study in our region. Its first aim was to assess the extent of biofouling on hard structures of marinas in Normandy, France; most of these reefs are formed by the alien Polychaeta $F$. enigmaticus. Referred to as an ecosystem engineer, F. enigmaticus strongly modifies resources and physical conditions by creating greater environmental heterogeneity and new micro-habitats. The second aim was thus to investigate the biodiversity of sessile or motile (vagile) fauna associated with these reefs, including both native and alien species.

\section{Materials and methods}

\subsection{Study sites and sampling design}


During the first phase of the study, explorations were conducted at least twice in 12 marina basins located in 9 different cities, from Cherbourg $\left(49^{\circ} 38^{\prime} \mathrm{N} / 1^{\circ} 37^{\prime} \mathrm{W}\right)$ to Honfleur $\left(49^{\circ} 25^{\prime} \mathrm{N} / 00^{\circ} 14^{\prime} \mathrm{W}\right)$ in Normandy, North-West France (Fig. 1). All basins were located in the city centres. The number of residents varied among cities, from 2,128 (Saint Vaast-la-Hougue, SVH) to 114,007 (Caen, CAE) in 2016, but increases significantly during the touristic season (Tab. 1). The marina depth varied from $1.5 \mathrm{~m}$ to $4 \mathrm{~m}$, and the water depth did not allow for the formation of a halocline or any pronounced stratification. Biofouling from port structures had not been removed in these basins for several years before this study. Except the marina in Saint Vaast-la-Hougue, which was directly influenced by seawater inputs, all marinas were partly filled with water from rivers. Initial explorations were taken on port structures, i.e. floating pontoons (wharfs) or the pillars of fixed pontoons (e.g. in Ouistreham, OUI) or sandstone walls in the old basin in Honfleur (HON) (Fig. 2a, b, c). These explorations took place over 2 weeks in January 2015, and aimed at identifying which basins had port structures colonized by $F$. enigmaticus. In each marina, 2 persons examined and scraped all kinds of port structures for at least $3 \mathrm{~h}$, and the sampling effort was considered sufficient to conclude the presence or absence of the worm species.

Water temperature and salinity were recorded twice with a field probe (HQ 30d; Hach ${ }^{\circledR}$, Loveland, CO, USA): a first time during the exploration period, and a second time on the $8^{\text {th }}$ and $9^{\text {th }}$ March (Tab. 1). Each measurement was triplicated at a depth of about $1 \mathrm{~m}$ that corresponded to the level where $F$. enigmaticus reefs were potentially well developed and easily accessible by sampling. In addition, during the second period of measurements, 3 water samples were collected and brought to the laboratory for $\mathrm{pH}$ measurements. Finally, a STPS10 probe (nke Instrumentation ${ }^{\circledR}$; Hennebont, France) was placed at a depth of $1 \mathrm{~m}$ in the marina of Carentan to record the annual fluctuations in water parameters (temperature, conductivity, pressure) at high frequency throughout 2015.

The basins where Ficopomatus enigmaticus was found (6 out of 12 marinas) were then selected for a one-time quantitative sampling spanning over the shortest period possible, i.e. one month in February 2015. This provided a snapshot of worm reefs during a period of low boat activity, when biofouling was less likely to be disturbed by sailing activities. Moreover, F. enigmaticus does not breed in winter (Dixon, 1981; Obenat and Pezzani, 1994), and so without spawning and recruitment, the populations are unlikely to fluctuate strongly over such a short period. In each marina basin, 15 samples of fauna forming biofouling were randomly collected on 3 different pontoons ( 5 samples per pontoon), located in the middle and at each extremity of the basin to capture potential spatial variation. Fouling organisms were collected on marina structures from the surface to a depth of 1-1.5 
m over a surface of $0.04 \mathrm{~m}^{2}(20 \times 20 \mathrm{~cm})$, using a homemade sampler (Fig. 2a, b). The entire content of each sample (i.e. biofouling, including tubeworms and all motile and sessile organisms) was then carefully placed into a plastic bag and brought to the laboratory where it was kept in a cold-room and processed within 24-48h at maximum.

\subsection{Sample treatment}

In the laboratory, each reef sample was first broken into smaller pieces to release the organisms trapped between the worm tubes. These subsamples were then carefully sorted to separate the motile fauna from sessile animals. For motile organisms, the 15 samples collected from each basin were pooled and immediately placed into a jar filled with $70 \%$ ethanol and preserved until examination. All individuals were observed under a binocular microscope, sorted by species and numbered. For sessile fauna, each of the 15 samples from a given basin was individually examined. Sessile animals were sorted and determined to the species level under a binocular microscope. Individuals of each species were numbered, except for $F$. enigmaticus which conglomerates in inextricable tubes. For each sample, the animals belonging to each species were separately stored in a freezer $\left(-20^{\circ} \mathrm{C}\right)$ before treatment. Tube-building worms and molluscs were processed without removing tubes or shells. After being defrosted, the volume of each species was rapidly assessed for each sample with overflow measuring flasks adapted to the range of biofouling volume. Finally, these subsamples were oven-dried for $48 \mathrm{~h}$ at $60^{\circ} \mathrm{C}$, then weighted to the nearest $0.001 \mathrm{~g}$. For each basin and each species forming biofouling, dry weight and volume were expressed as a mean \pm Standard Error around the Mean (SEM).

\subsection{Data analysis and statistics}

Frequency (i.e. the frequency of occurrence in the marinas where a taxa was found divided by the total number of marinas with $F$. enigmaticus) and density (i.e. number of individuals per $\mathrm{m}^{-2}$ ) were calculated for each taxon. For each marina, the species richness and density were studied by considering 1) the sessile fauna only; 2) the motile fauna only and 3) all species (sessile + motile fauna, except $F$. enigmaticus that cannot be counted). In addition, the Shannon diversity index ( $\left.H^{\prime}\right)$ and evenness $(E)$ were calculated as follows: $H^{\prime}=\sum p_{i}\left(\log _{2}\left(p_{i}\right)\right)$, where $p_{i}=$ abundance of taxon $i$ / total abundance; $E=H^{\prime} / \log _{2}(S)$, where $S$ is the species richness. 
Similarity in species assemblages was investigated between pairs of marinas by computing the Sørensen similarity index $\left(\mathrm{S}_{\mathrm{or}}\right)$ (Jongman et al., 1995), as $S_{\text {or }}=2 C /(A+B)$, where $C$ is the number of species shared by the two marinas considered, and A and B the species richness of the two marinas. $S_{\text {or }}$ is expressed in percentage, and varies between 0\% (no common species) and 100\% (same species richness and composition).

Differences in water parameters (temperature, salinity and $\mathrm{pH}$ ) were tested between marinas with and without $F$. enigmaticus reefs by applying $t$-tests, or Mann-Whitney (M-W) tests when assumptions of normality and homoscedasticity were not met. Differences in biofouling volume and dry weight among marinas (6 groups) were analyzed with non-parametric Kruskal-Wallis (K-W) tests for the same reason. When a significant difference was detected, pairwise post-hoc Dunn tests were applied to compare biofouling and dry weight among marinas.

\section{Results}

\subsection{Water parameters}

Annual variability in water parameters in the marina of Carentan showed a marked seasonality in both temperature and salinity (Fig. 3). During the explorations, i.e. over the course of 2 weeks in January 2015 , water temperature ranged from $6.00^{\circ} \mathrm{C} \pm 0.06 \mathrm{SEM}$ in the marina of Carentan (CAR) to $7.60^{\circ} \mathrm{C} \pm 0.06 \mathrm{SEM}$ in the outer-port basin of Cherbourg (CHOP); the average temperature in the 12 marinas was $6.65^{\circ} \mathrm{C} \pm 0.09 \mathrm{SEM}$. On the $8^{\text {th }}$ and $9^{\text {th }}$ March, the minimum and maximum values were recorded in the same marinas as during the explorations period, reaching $7.23^{\circ} \mathrm{C} \pm 0.03 \mathrm{SEM}$ in $\mathrm{CAR}$ and $8.67^{\circ} \mathrm{C} \pm 0.07 \mathrm{SEM}$ in $\mathrm{CHOP}$, with an overall average temperature of $7.84^{\circ} \mathrm{C} \pm 0.09 \mathrm{SEM}$.

Over the two measurement periods, the lowest and highest salinity values were $0.13\left(\mathrm{CAE} ; 1^{\text {st }}\right.$ record) and 32.57 (SVH; $1^{\text {st }}$ record), respectively (Tab. 1). The highest differences in water salinity between the two measurement periods were recorded at Courseulles-sur-Mer Ile de Plaisance (CIPB; +19.07) and Cabourg (CAB; -9.92). Considering the following typology: freshwater < $0.5 ; 0.5<$ oligohaline $<5 ; 5<$ mesohaline $<18 ; 18<$ polyhaline $<30$ and euhaline $>30$, the marinas could be classified as follows: freshwater/oligohaline: CAE; oligohaline: HON; oligo-/mesohaline: CAR; mesohaline: OUI and CHOP; meso-/polyhaline: CIPB and Deauville Morny basin (DMOB); polyhaline: CAB, Deauville Marina (DMB), Courseulles-sur-Mer Joinville basin (CJB) and Cherbourg Chantereyne basin $(\mathrm{CHCH})$ and euhaline: SVH. The classification of CAR into the category oligo-mesohaline waters was confirmed by the high-frequency monitoring of water parameters in this marina, throughout 2015 (Fig. 3), and may apply to the other marinas. 
Low inter-marina differences were noticed in water $\mathrm{pH}$, with values ranging from $7.80(\mathrm{CAB})$ to 8.05 (CAR) (Tab. 1).

\subsection{Occurrences of F. enigmaticus}

Reefs built by $F$. enigmaticus were found in 6 marina basins: CAR, CJB, CIPB, OUI, CAE and HON. By contrast, this serpulid species was not seen on the marina structures of four cities, from the West to the East: Cherbourg (CHOP and $\mathrm{CHCH}$ ), SVH, CAB and Deauville (DMB and DMOB). The most distant cities (Cherbourg vs Honfleur) are separated by $140 \mathrm{~km}$, and all study marina are located in the same temperate-oceanic climate. Therefore, water temperature did not significantly differ between marinas with or without $F$. enigmaticus in all measurements (M-W test; $p=0.54$ ) (Fig. 4) or those made over only 2 days (M-W test; $p=0.87)$. Similarly, $\mathrm{pH}$ did not show significant differences between the two groups of marinas (M-W test; $p=0.29$ ) (Fig. 4). Salinity may vary according to many parameters such as port management (i.e. frequency of lock opening), rainfall events as well as tide (schedule and coefficient). Overall, the water salinity of marina without $F$. enigmaticus averaged $23.80 \pm 1.03$ SEM against $9.78 \pm 1.61$ SEM when this worm was present (Fig. $4)$, and the differences were highly significant ( $\mathrm{M}-\mathrm{W}$ test; $p=0.001)$. Water salinity was also significantly lower in marinas populated by $F$. enigmaticus during both recording periods when tested separately for each measurement period (January, 8.15 \pm 1.57 SEM vs 24.00 \pm 1.44 SEM; $t$ test; $p=0.001 ; 8^{\text {th }}$ and $9^{\text {th }}$ March, $11.41 \pm 2.81$ SEM $v s 23.61 \pm 1.50$ SEM; $t$-test; $\left.p=0.036\right)$. Finally, $F$. enigmaticus indifferently settled on all kinds of marina structures (i.e. wood, polyvinyl chloride, polyester resin, aluminum, and partially block of stone at $\mathrm{HON}$ ).

\subsection{Importance of biofouling in the 6 marinas populated by F. enigmaticus}

In the six marinas populated by $F$. enigmaticus (Tab. 2), the total volume of biofouling per 0.04 $\mathrm{m}^{2}$ ranged from $8.49 \mathrm{~mL} \pm 0.80 \mathrm{SEM}$ at $\mathrm{CAE}$ to $459.52 \mathrm{~mL} \pm 31.47 \mathrm{SEM}$ at $\mathrm{HON}$, and significant inter-site differences were recorded (K-W test and Dunn tests; $p<0.001)$ (Fig. 5). Similar results were found with dry weight, with extreme values per $0.04 \mathrm{~m}^{2}$ ranging from $6.69 \mathrm{~g} \pm 0.62 \mathrm{SEM}$ (CAE) to $178.61 \mathrm{~g} \pm 25.50 \mathrm{SEM}$ (OUI). In these basins, F. enigmaticus was accompanied by 4 taxa (species or genus sp.): the barnacle Balanus improvisus (4 marinas); the dark false mussel, Mytilopsis leucophaeata (3 marinas); the softshell clam, Mya arenaria (1 marina) and the ascidian genus Molgula sp (1 marina) (Tab. 3). By contrast, no sessile organisms colonized the reefs at CIPB. Ficopomatus enigmaticus greatly dominated the invertebrate communities both in volume (74-100\%) 
and weight (70-100\%), except at CAE (12\% and 11\%, respectively) where B. improvisus population was the most abundant (Fig. 6). The three main species in terms of contribution to the biofouling (i.e. F. enigmaticus, M. leucophaeata and B. improvisus) showed significant inter-sites differences (K-W test and Dunn tests; $p<0.01$ ) (Fig. 7). For example, the reefs built by $F$. enigmaticus were extremely limited at CAE, and about 3 times larger at $\mathrm{HON}$ in comparison with both marinas of Courseulles (CJB and CIPB). Lesser but significant differences were recorded with dry weight. The biofouling on the marina structures at OUI was characterized by a non-negligible volume $(63.00 \mathrm{~mL} \pm 9.67 \mathrm{SEM})$ and dry weight (37.86 $\mathrm{g} \pm 5.96 \mathrm{SEM}$ ) of B. improvisus whereas the volume of this barnacle was 12 to 107 times lower in the three other marinas where it could be observed. The biofouling formed by the mussel M. leucophaeata was more developed at OUI compared to CAR and CAE but post-hoc tests revealed significant differences in volume and dry weight only with CAE (Dunn tests; $p<0.001$ ). Finally, B. improvisus was more abundant than $M$. leucophaeata $\left(3,587\right.$ vs 2,146 ind m$^{-2}$,

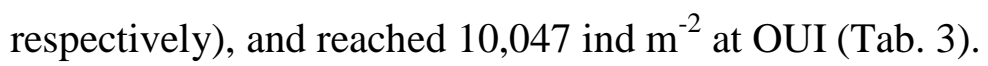

\subsection{Communities of sessile and motile invertebrate faunas associated with reefs built by $F$. enigmaticus}

A total of 20 sessile or motile invertebrate taxa (species, genus or sub-families) were collected in the six marinas populated by F. enigmaticus, and the species richness ranged from 6 (HON) to 11 (CJB) (Tab. 2). Out of the 17 taxa determined to the species level, 7 have been reported to be alien, especially those forming fouling (4/4 vs 3/13 for vagile species). However, the status is not clarified for two species which are sometimes qualified as cryptogenic species: Physella (= Physa) acuta (Garcia-Berthou et al., 2007) and Monocorophium sextonae (Dewarumez et al., 2011). The sea squirt of the genus Molgula might correspond to the species Molgula manhattensis, introduced from Western Atlantic to Europe in $18^{\text {th }}$ century (initially in The Netherlands), and in France in $19^{\text {th }}$ century; this sea squirt species has been reported in French ports, e.g. Le Havre before the end of 1970s (Breton, 2014).

Except F. enigmaticus, the three most frequent species (83.33\%) were: the Annelida Polychaeta, Nereis zonata, the Amphipoda, Gammarus zaddachi and the crab, Rhithropanopeus harrisi (formerly Heteropanope tridentatus). The Sørensen index $\left(\mathrm{S}_{\mathrm{or}}\right)$, measuring the similarity between pairs of marinas, ranged from $21.05 \%$ (CJB-CAE) to $90.00 \%$ (CAR-OUI), with an average of $54.59 \% \pm 5.62$ SEM (Tab. 3). Finally, four fish species were also trapped into the sampler: Anguilla anguilla (12 
individuals in total at CAR, CJB, CIPB and OUI); Lipophrys pholis (1 individual at both CJB and CIPB); Coryphoblennius galerita and Gobius paganellus (only 1 individual both at CIPB).

When considering only motile organisms associated with biofouling, a total of 2,168 individuals belonging to 15 different taxa were identified from the 90 samples collected in the 6 marinas. Most species were crustaceans: Amphipoda $(n=4)$; Isopoda $(n=2)$ and Decapoda Brachyura $(n=4)$; but one Pulmonata snail, two species of Polychaeta and two sub-families of Insecta Diptera Chrinomidae were also collected (Tab. 2). The motile species richness ranged from 4 at HON to 9 in both marinas of Courseulles. CAE and HON did not share common species whereas CJB and CIPB shared 8 out of 9 species, and in these 2 marinas, the particular species was represented by only one individual. Finally, $S_{\text {or }}$ averaged $49.68 \%( \pm 8.22 \mathrm{SEM})$, i.e. about $5 \%$ less than $\mathrm{S}_{\text {or }}$ mean value taking all taxa into account (Tab. 3). The motile invertebrate communities from CAR and OUI showed the highest level of similarity $\left(\mathrm{S}_{\mathrm{or}}=92.31 \%\right)$ while the communities collected at CAE showed the greatest differences with those from both CJB and CIPB (14.29\%) and above all from HON (no shared taxa: $\mathrm{S}_{\mathrm{or}}=0 \%$ ). The taxonomic richness of sessile fauna and of motile taxa were not significantly correlated both when CIPB (only F. enigmaticus present as a sessile species) was considered $(\mathrm{r}=0.146 ; n=6 ; p>0.05)$ or excluded from the calculation $(r=0.141 ; n=5 ; p>0.05)$.

When omitting $F$. enigmaticus, density of organisms forming biofouling displayed strong variations, ranging from 0 (at CIPB: no accompanied species) to $11,715 \mathrm{ind}^{-2}$ in OUI (Tab. 2). The biofouling in this marina also hosted the highest number of motile individuals $\left(1,532 \mathrm{ind} \mathrm{m}^{-2}\right.$, all species combined) as opposed to both marinas in Courseulles where they displayed the two lowest animal densities (127 and 130 ind $\mathrm{m}^{-2}$ at CJB and CIPB, respectively). Among vagile fauna, Rhithropanopeus harrisi showed the highest mean density with 341.67 ind $\mathrm{m}^{-2}$. The species was particularly abundant at OUI $\left(1,076.67 \mathrm{ind}^{-2}\right)$ but showed large among-marina differences (SEM of 194.12). Finally, a significant correlation was observed between the global densities of sessile (except $F$. enigmaticus) and motile fauna, all taxa combined (e.g. $r=0.824 ; n=5 ; p<0.05$ without CIPB). When considering the volume of the three main sessile taxa instead of density, the density of motile fauna was significantly correlated with volume of B. improvisus $(r=0.911 ; n=4 ; p<0.05)$ and M. leucophaeata $(r=0.993 ; n=3 ; p<0.05)$ but not with that of $F$. enigmaticus $(r=0.421 ; n=6 ; p>0.05)$.

For both motile species communities and all species combined (sessile and motile), the highest Shannon diversity index $\left(H^{\prime}\right)$ and evenness $(E)$ were recorded at CJB $\left(H^{\prime}=2.74\right.$ and $E=0.87$, and $H^{\prime}=2.73$ and $E=0.82$, respectively) (Tab. 2). The bulky biofouling at HON (Fig. 5) was populated by the lowest diversity of vagile fauna (0.72), which showed a low evenness (0.45). Nevertheless, when 
all species were considered, diversity increased to $H^{\prime}=1.39$ due to a relatively high evenness $(E=0.60)$. The lowest diversity $\left(H^{\prime}=1.18\right)$ and evenness $(E=0.37)$ were recorded at OUI.

\section{Discussion}

\subsection{F. enigmaticus distribution in Normandy marinas}

The Australian tube worm F. enigmaticus was first observed in Europe in 1921. It was found in Normandy, in the canal leading from Caen to the English Channel. This annelid is now widely disseminated and is currently present along much of the European coastline, including the Channel (e.g. Fornos et al., 1997; Zhulidov et al., 2015), the Atlantic coasts (Dewarumez et al., 2011), and the entrance of the Baltic Sea (e.g. Dittmann et al., 2009). The absence of F. enigmaticus in 6 out of the 12 explored marinas can therefore not be explained by its status of introduced species and its current biogeographic distribution. Caution is needed because records were made only over a limited period, but among the water parameters considered (i.e. temperature, $\mathrm{pH}$ and salinity), salinity appeared as the most discriminatory factor at the regional scale. Ficopomatus enigmaticus was mainly collected in oligohaline (0.5-5) to mesohaline (5-18) marinas, and the salinity of these basins was significantly lower than in basins where the species was absent. Moreover, the worm reefs were the most voluminous in the three marinas (HON, CAR and OUI) with a maximum salinity of 9.98 (CAR); the survey conducted in this marina for 13 months in 2015 showed the average monthly salinity ranged from 7.13 to 15.04 (Fig. 3). The various records made at OUI confirmed the mesohaline nature of this marina (unpublished results). However, Joinville basin in Courseulles (CJB) was populated by F. enigmaticus and showed salinity values as high as 20.64 and 28.53 . This population might originate from the connected basin of CIPB that showed among the highest fluctuations in salinity over the course of this study (7.56 during the first measurement and 26.63 during the second one). Ficopomatus enigmaticus is a cosmopolitan brackish species with a high tolerance to salinity fluctuations (e.g. Straughan, 1972; ten Hove and Weerdenburg, 1978; Dittmann et al., 2009). It can survive in salinity ranging from 1.5 to 50-55 (DAISIE, 2017; Day, 1981); this physiological flexibility may have contributed to its worldwide expansion. The preferred habitat of F. enigmaticus for reproduction remains brackish waters with a variable salinity of 6-35 (Straughan, 1972). The scarce development of $F$. enigmaticus reefs in CAE may therefore be due to the very low salinity $(<1.90)$ and this worm population may be considered as a relict. Other factors may impact the species distribution, including the substratum, although the species was already observed on 
reeds, shells or objects dispersed in soft bottoms (Bianchi and Morri, 2001). The most extensive reef development occurred on the stone walls at HON but the present study supports a limited influence of the substratum, as the materials of marina structures where $F$. enigmaticus settled were indifferently made of stone blocks at $\mathrm{HON}$, and various materials in the other marinas. Further studies may therefore explore other hard bottoms around HON.

Ficopomatus enigmaticus is as a filter-feeder that is abundant in low current and turbid waters with high nutrients levels. This species is highly resistant to pollution but sensitive to wave intensity (e.g. Ditmann et al., 2009; DAISIE, 2018; ISSG, 2018). In the present study, F. enigmaticus dominated the invertebrate communities fouling the marina structures, and really acted as an engineer species (except at CAE). The reefs built by F. enigmaticus were as high as $\sim 0.4 \mathrm{~m}$ on the vertical stone walls at HON, and seemed to break under their own weight, in line with observations from other locations: $0.5 \mathrm{~m}$ in height in an Argentina estuary (Obenat and Pezzani, 1994; Schwindt et al., 2004); up to $1 \mathrm{~m}$ and with average worm densities of $\sim 8.88$ million $\mathrm{m}^{-3}$ in the Italian Adriatic coast (Bianchi and Morri, 1996). Only the uppermost layer ( $10 \mathrm{~cm}$ thick) contains living worms (Bianchi and Morri, 1996), explaining the deeper layer of empty tubes that had turned black due to reducing conditions at $\mathrm{HON}$, while the very thin innermost layer was white, possibly due to diagenetic processes (Fig. 2d). The impact of F. enigmaticus may thus extend beyond death.

\subsection{Fouling species associated with F. enigmaticus}

Four other fouling species settled on the marina structures and/or the calcareous tubes built by $F$. enigmaticus, including the ascidian Molgula sp. (possibly M. manhattensis). This ascidian and the bivalve Mya arenaria are brackish-marine organisms, and each was collected in a single marina (CJB and CAR, respectively), always in low density. Although these two species may have a limited impact on the functioning of the hard-bottom communities, they are alien species and should therefore be monitored. Balanus improvisus is a cosmopolitan barnacle introduced in Europe from the $13^{\text {th }}$ century and reported in The Netherlands in 1827 (Dewarumez et al., 2011). Balanus improvisus likely originated from the American Atlantic coasts but, it sometimes is considered a cryptogenic species. This hermaphrodite species can be a facultative self-fertilizer (Furman and Yule, 1990), and is well-known for its high tolerance to variations in salinity (Dewarumez et al., 2011; DAISIE, 2018). In laboratory, B. improvisus settled over a wide range of salinity (2-35), with a peak at 15 (Dineen and Hines, 1992). During experiments to test anti-fouling films, Oliva et al. 
(2017) observed that higher numbers of the cyprids of B. improvisus settled on all test surfaces than those of Balanus amphitrite; highlighting its ability to invade diverse habitats. In the present study, B. improvisus dominated (59.65\%) the attached community at CAE but formed a poorly developed fouling $(5.07 \mathrm{~mL}$ and $4.56 \mathrm{~g})$, likely explained by the very low salinity level. Contrastingly, in OUI where fouling was well developed $(\sim 326 \mathrm{~mL}$ and $178 \mathrm{~g})$, this barnacle represented only $19.32 \%$ of the total biovolume yet it displayed the highest recorded biovolume $(63 \mathrm{~mL})$ and dry weight $(37.86$ g). The second species that significantly contributed to fouling in three marinas populated by $F$. enigmaticus was the false dark mussel, Mytilopsis leucophaeata. This dreissenid species was observed for the first time in France in 1921 in the canal from Caen to the Channel, where it lived in association with F. enigmaticus (Fauvel, 1923). Today, M. leucophaeata is widely distributed in Europe thanks to its broad habitat preferences (Verween et al., 2010; Kennedy, 2011). An abundant population in the freshwater-oligohaline marina of Caen would have been expected because conditions are within the species habitat preferences, but it was only comparable to that of OUI and less abundant than in CAR. Moreover, the individuals collected in CAE were especially small (mean dry weight of $0.02 \mathrm{~g} \pm 0.002 \mathrm{SEM})$ with comparison with those of CAR $(0.06 \mathrm{~g} \pm 0.01 \mathrm{SEM})$ and OUI $(0.23 \mathrm{~g} \pm 0.01 \mathrm{SEM})$. The lower abundances in Caen may be explained by its location in the centre of the most populated city $(\sim 114,000$ inhabitants and $\sim 200,000$ with the urban agglomeration), where more significant anthropic pressure may reduce the development of attached organisms. Although M. leucophaeata can settle on various substrates (Verween et al., 2010) and be present alone in freshwater habitats in Normandy (unpublished results), it was never encountered without $F$. enigmaticus in brackish marinas.

\subsection{Impact of biofouling in marinas}

One of the main results of the present study is the great inter-site variation in biofouling volume and weight, even though the study was conducted during the winter to minimize the volume of biofouling (Floert, 2005). For all marinas, biofouling was perceived as a nuisance for boaters and harbor masters. It was particularly damaging in HON, where $F$. enigmaticus reefs have been nicknamed "la gale honfleuraise" (Honfleur scrab). In Le Havre harbor, a dystrophic crisis occurring in summer 2003 induced the death of all fouling organisms (except Mytilus edulis), but as soon as January 2004, F. enigmaticus recolonized 95\% of the available substrates (Breton, 2014). Ficopomatus enigmaticus is an "aggressive" species that dominates habitats and is extremely 
common in harbors and on ship hulls; it may also cause problems in cooling intakes of power plants and in aquaculture ponds, requiring frequent cleaning (ISSG, 2018; DAISIE, 2018).

Fouling organisms may also have harmful economical and ecological consequences. For example, B. improvisus, a species associated with $F$. enigmaticus, alters habitat and damages shellfish aquaculture by competing for space and food, and fouling mussel and oyster banks or livestocks (Dewarumez et al., 2011; DAISIE, 2017). Another associated species, M. leucophaeata, displays a greater resistance to anti-fouling techniques compared to Dreissena polymorpha and M. edulis (Verween et al., 2010). High rates of biodeposition contribute to environmental siltation, and this is likely induced by the duo F. enigmaticus-M. leucophaeata (recorded filtration rates of $8.59 \mathrm{~mL} \mathrm{~h}^{-}$ ${ }^{1} \mathrm{mg}^{-1}$ (Davies et al., 1989) and $55 \mathrm{~mL} \mathrm{~h}^{-1}$ mussel $^{-1}$ at $20^{\circ} \mathrm{C}$ (Rajagopal et al., 2005), respectively). Ficopomatus enigmaticus and all associated attached species found here are therefore efficient filterfeeders able to compete with indigenous species for food and space (Dewarumez et al., 2011), by depleting phytoplanktonic and suspended particulate organic resources used by native filter-feeders (e.g. Eno et al., 1997). Such assertions remain general and difficult to verify without an inventory of the native communities before the introduction of these alien species. The highest invasive species richness occurred in habitats with high native species richness, indicating that the main factors driving native species distribution are also driving aquatic invaders (Zaiko et al., 2007).

The presence of $F$. enigmaticus in eutrophic environments or enclosed waters, including marinas, may also have very beneficial effects on water quality, reducing suspended particulate loads and improving both the oxygen and nutrient status (Davies et al., 1989). Through the production of feces and pseudofeces, this worm concentrates contaminants and passes them into the sediments, enhancing the food chain (Eno et al., 1997). Positive interactions between F. enigmaticus and macroalgae communities have also been reported by Bazterrica et al. (2013; 2014). Finally, F. enigmaticus reefs generate topographic heterogeneity that modifies hydrodynamics and sediment transport (Swindt et al., 2004), and creates micro-habitats where various organisms may find a shelter. In the present study, M. leucophaeata profited from the presence of $F$. enigmaticus since the mussels were found at the base of the reefs (Fig. 2e, f), and were therefore protected from predators like eels, observed in high numbers in CAR and OUI. The four fish species caught were opportunistic feeders (Anguilla anguilla, two blennid and one gobiid species), predating on invertebrates, including worms and mussels (DORIS, 2018). A total of 15 motile taxa (13 species and two sub-families of insects Diptera Chironomidae) were collected along with F. enigmaticus. With four taxa specific to CAE and a low average $S_{\text {or }}(12.68 \pm 3.26$ SEM), this marina had a different invertebrate community than the other marinas. While the amphipod species (Leptocheirus 
tricristatus and the alien or cryptogenic species Monocorophium sextonae) can live in a wide range of salinities, the chironomids and the gastropod Physella acuta are considered freshwater species (Zukowski and Walter, 2009). Surprisingly, HON, classified as an oligohaline marina, shared no common species with CAE, although the sub-family Chironomidae was present in both. These results show that the distribution patterns of invertebrate assemblages in marinas result from a set of complex interactions between species and environmental drivers, with salinity likely being the most important factor (Joyce et al., 2005). The motile communities associated with $F$. engimaticus reefs in the marinas of Carentan, Courseulles (CIPB and especially CJB) and Ouistreham showed a high degree of similarity $\left(66.67<\mathrm{S}_{\text {or }}<92.31\right)$. These marinas were populated by a common community of brackish/marine polychaetes (Nereis zonata and Alitta succinea) and crustaceans including Amphipoda and Decapoda. Among these taxa, the case of Rhithropanopeus harrisi is particularly interesting as this alien crab showed the highest densities in the marinas of Honfleur and Ouistreham (572 and 1,077 ind $\mathrm{m}^{-2}$, respectively), as illustrated by the low values of diversity and equitability at OUI (e.g. 0.72 and 0.45, respectively). Originating from North America, R. harrisii was first observed in Europe in 1874 and later spread to the North Sea and the Baltic Sea (Fowler et al., 2013). Its presence in Normandy was first reported in the 1950s (Saudray, 1956) but its current distribution in France remains poorly described (INPN, 2018b). In its native range, it can only be found in a very specific habitat; however, in Finland, it colonizes almost all types of available habitats. Thus, predictions of its invasion potential cannot solely rely on prior knowledge of habitat preference (Fowler et al., 2013). Rhithropanopeus harrisi larvae may survive in salinities of $2.5-40$ (Boyle et al., 2010; Fowler et al., 2013). In the present study, F. enigmaticus reefs appeared to be favorable to crabs, offering shelter and food resources as showed by Luppi et al. (2002) for the megalopae of the crab Cyrtograpsus angulatus.

While relationships were detected in other locations (Dean, 1981), in the present study, the richness of sessile and of motile taxa were not significantly correlated suggesting that $F$ enigmaticus reefs were sufficient to shelter a relative high number of vagile species, as observed in the two marinas of Courseulles. The global densities of attached and motile species (all species combined) were significantly correlated. Favorable environmental conditions may have triggered a high development of both sessile and vagile populations. The presence of $F$. enigmaticus reefs may play a role, although mutual positive interactions between the two types of species/communities should not be excluded. Several studies assessed the impact of M. edulis and B. improvisus on the fouling community. Studies showed a negative effect of the mussels on community structure (Dürr and Wahl (2004), and a positive effect of barnacles plates on the heterogeneity of the habitat (Bros, 1987). In the present study, the density of motile fauna was significantly correlated with the volume of $B$. 
improvisus and M. leucophaeata (maybe due to the hypotheses previously mentioned) but not with that of F. enigmaticus. The absence of correlation between the density of vagile fauna and the volume of worm reefs suggest that only the uppermost layer of the reefs may be appropriate to shelter motile organisms. The observations presented here suggest the latter hypothesis may apply, i.e. the positive impact of $F$. enigmaticus on invertebrate communities depends on the "quality" of the reef more than on its volume (Fig. $2 \mathrm{~d} v s$ 2e). In South Africa, F. enigmaticus reefs support a greater biomass of infauna than adjacent sandy areas, with a positive correlation between the reef mass and infaunal biomass, density and diversity (McQuaid and Griffiths, 2014). The impact of these reefs may also be detected on higher trophic levels, including birds (Bruschetti et al., 2009). In this framework, it would be interesting to collect sessile and motile fauna on hard substrates with and without reefs in the same marinas of Normandy to determine whether the impact of F. enigmaticus is limited to the local invertebrate communities or if it may expand to the whole food web.

\subsection{Future potential expansion of F. enigmaticus}

In the frame of global change and increasing pollution level, field studies focused on $F$. enigmaticus may be particularly useful as this worm species is a solid candidate organism for ecotoxicological assays in brackish and marine waters (Oliva et al., 2018). At the regional scale of the present study, water temperature did not appear to be a crucial parameter explaining the presence and the extent of worm reefs. Ficopomatus enigmaticus spawns when the water temperature exceeds $18^{\circ} \mathrm{C}$ (Obenat and Pezzani, 1994; Fornos et al., 1997), with the most settlement occurring at water temperatures from $18^{\circ} \mathrm{C}$ to $24^{\circ} \mathrm{C}$ (Bianchi and Morri, 1996). The $18^{\circ} \mathrm{C}$ threshold, required to induce extensive spawning, is generally reached on the French coasts of the Channel, and particularly in marinas that are semi-enclosed ecosystems (Fig. 3). At the European scale, given that F. enigmaticus is found on various substrates (e.g. present study and Fornos et al., 1997), and its wide physiological tolerance to low salinity levels (DAISIE, 2017, and Fig. 4), it is likely that the northern distribution may be limited by the maximum seawater temperature (e.g. Dittmann et al., 2009). This is further supported by the distribution of areas where the annual sea surface temperature (SST) reaches $>18^{\circ} \mathrm{C}$ at least once (Fig. 8), which matches the reported distribution of the species in European waters (i.e. Mediterranean Sea, Channel, South of UK, South of the North Sea, and entrance of the Baltic Sea where it may be currently limited to the warmest regions; DAISIE, 2018; Dittmann et al., 2009). The present study shows that low salinity is not a limiting factor, so if water temperature actually triggers the northern spread of $F$. enigmaticus, the projections of SST suggest that favorable spawning 
conditions may develop much further North by the end of the $21^{\text {st }}$ century (Fig. 8). By 2040, the sea surface temperature may exceed $18^{\circ} \mathrm{C}$ throughout the North Sea from Denmark to South of Scotland, as well as in the most Eastern and Northern parts of the Baltic Sea (Fig. 8). By 2080, favorable conditions may even expand to most of the Baltic Sea, and reach parts of the UK such as Scotland and North Ireland. Although these model projections remain hypothetical, the worldwide expansion of F. enigmaticus will likely continue as temperatures keep rising. Ficopomatus enigmaticus may even end up colonizing new ecosystems such as the Baltic Sea, which oligohaline conditions would actually not prevent this invasion.

\section{Conclusion}

This exploratory study assessed the presence of $F$. enigmaticus in Normandy, which had never been monitored since its discovery in the canal of Caen. It provides a snapshot of the distribution of F. enigmaticus and of the extent of the reefs it forms in the marinas of Normandy. Biofouling dominated by F. enigmaticus is known to be an s economical nuisance, and this study shows that the species also has an ecological impact by offering favourable habitat to two other alien sessile species, B. improvisus and $M$. leucophaeata. It was also a habitat to a pollution-resistant invertebrate community composed of polychaetes and crustaceans, largely dominated by the alien crab R. harrisi. Artificial environments such as marinas remain poorly studied, and the lack of data on native fauna makes it difficult to assess the impact of alien species on these brackish ecosystems. In the framework of global change, it is essential to understand the dynamics of invasive species. This understanding can only be achieved by monitoring species of growing concern and associated fauna; F. enigmaticus reefs are no exception.

\section{Acknowledgments}

We gratefully acknowledge the staff of the UMR BOREA in the University of Caen Normandie and particularly Jean-Marc Lebel and Antoine Serpentini for help; and Christophe Roger for his assistance in field work.

\section{References}


Bazterrica, M.C., Alvarez, M.F., Bruschetti, C.M., Hidalgo, F.J., Fanjul, M.E., Iribarne, O., Botto, F. 2013. Factors controlling macroalgae assemblages in a Southwest Atlantic coastal lagoon modified by an invading reef forming polychaete. Journal of Experimental Marine Biology and Ecology, 443, 169-177. https://doi.org/10.1016/j.jembe.2013.02.036

Bazterrica, M.C., Bruschetti, C.M., Alvarez, M.F., Iribane, O., Botto, F. 2014. Effects of macroalgae on the recruitment, growth, and body condition of an invasive reef forming polychaete in a southwestern Atlantic. Journal of Sea Research, 88, 121-129. http://dx.doi.org/10.1016/j.seares.2014.01.002

Bianchi, C.N., Morri, C. 1996. Ficopomatus 'reefs' in the Po River Delta (Northern Adriatic): their constructional dynamics, biology, and influences on the brackish-water biota. Marine Ecology, 17 $(1-3), 51-66$.

Bianchi, C.N., Morri, C. 2001. The battle is not to the strong: serpulid reefs in the Lagoon of Orbetelloà (Tuscany, Italy). Estuarine, Coastal and Shelf Science, 53, 215-220.

Boyle, T. Jr., Keith, D., Pfau, R. 2010. Occurence, reproduction, and population genetics of the estuarine mud crab, Rhithropanopeus harrisii (Gould) (Decapoda, Panopidae) in Texas freshwater reservoirs. Crustaceana 83(4): 493-505. http://dx.doi.org/10.1163/001121610X492148

Breton, G. 2014. Espèces introduites ou invasives des ports du Havre, d'Antifer et de Rouen (Normandie, $\quad$ France). Hydroécologie Appliquée, $\quad 18, \quad$ 23-65. https://www.hydroecologie.org/articles/hydro/pdf/2014/01/hydro140003.pdf

Bros, W.E. 1987. Effects of removing or adding structure (barnacle shells) on recruitment to a fouling community in Tampa Bay, Florida, USA. Journal of Experimental Marine Biology and Ecology, 105 (2-3), 275- 296. 
Bruschetti, M., Luppi, T., Fanjul, E., Rosenthal, A., Iribarne, O. 2008. Grazing effect of the invasive reef-forming polychaete Ficopomatus enigmaticus (Fauvel) on phytoplankton biomass in a SW Atlantic coastal lagoon. Journal of Experimental Marine Biology and Ecology, 354, 212-219. https://doi.org/10.1016/j.jembe.2007.11.009

Bruschetti, M., Bazterrica, C., Luppi, T., Iribarne, O. 2009. An invasive intertidal reef-forming polychaete affect habitat use and feeding behavior of migratory and locals birds in a SW Atlantic coastal lagoon. Journal of Experimental Marine Biology and Ecology, 375, 76-83. https://doi.org/10.1016/j.jembe.2009.05.008

Craig, J.B., Eaton, R.A., Thorp, C.H. 2001. Effects of chromated copper arsenate (CCA) wood preservative on early fouling community formation. Marine Pollution Bulletin, 42(11), 1103-1113. https://doi.org/10.1016/S0025-326X(01)00095-9

DAISIE (Delivering Alien Invasive Species Inventories for Europe). 2018. Search for information on one of the 12122 alien species occurring in Europe. http://www.europe-aliens.org/ (accessed in June 2018)

Davies, B.R., Stuart, V., de Villiers, M. 1989. The filtration activity of a serpulid polychaeta population (Ficopomatus enigmaticus Fauvel) and its effects on water quality in a coastal marina. Estuarine, Coastal and Shelf Science, 29, 613-620. https://doi.org/10.1016/0272-7714(89)90014-0

Day, J. H. 1981 The estuarine fauna. In: Estuarine Ecology with Particular Reference to Southern Africa. Day, J. H. (ed.)., A. A. Balkema, Rotherdam (The Netherlands), pp. 147-178.

Dean T.A. 1981. Structural aspects of sessile invertebrates as organizing forces in an estuarine fouling community. Journal of Experimental Marine Biology and Ecology, 53, 163-180. https://doi.org/10.1016/0022-0981(81)90017-4 
de los Ríos, A., Pérez, L., Echavarri-Erasun, B., Serrano, T., Barbero, M.C., Ortiz-Zarragoitia, M., Orbea, A., Juanes, J.A., Cajaraville., M.P. 2016. Measuring biological responses at different levels of organisation to assess the effects of diffuse contamination derived from harbour and industrial activities in estuarine areas. Marine Pollution Bulletin, 103, 301-312. https://doi.org/10.1016/j.marpolbul.2015.11.056

Dewarumez, J.M., Gevaert, F., Massé C., Foveau, A., Desroy, N., Grulois, D., 2011. Les espèces marines animales et végétales introduites dans le bassin Artois-Picardie. Report UMR CNRS 8187 LOG et Agence de l'Eau Artois-Picardie. $140 \quad$ p. http://archimer.ifremer.fr/doc/00158/26894/25125.pdf

Dineen, J.F., Hines, A.H. 1992. Interactive effects of salinity and adult extract upon settlement of the estuarine barnacle Balanus improvisus (Darwin, 1854). Journal of Experimental Marine Biology and Ecology, 156, 239-252. https://doi.org/10.1016/0022-0981(92)90249-A

Dittmann, S., Rolston, A., Benger, S. N., et Kupriyanova, E. K. 2009. Habitat requirements, distribution and colonisation of the tubeworm Ficopomatus enigmaticus in the Lower Lakes and Coorong. Report for the South Australian Murray-Darling Basin Natural Resources Management Board, 98 p.

Dixon, D.R. 1981. The reproductive biology of the serpulid Ficopomatus (Mercierella) enigmaticus in the Thames Estuary, SE England. Journal of the Marine Biological Association UK, 61, 805-815. https://doi.org/10.1017/S0025315400048220

DORIS (Données d'Observations pour la Reconnaissance et l'Identification de la faune et la flore Subaquatiques). 2018. Rechercher parmi 3986 espèces. http://doris.ffessm.fr/ (accessed in June 2018). 
Dunham, J.B., Adams, S.B., Schroeter, R.E., Novinger, D.C. 2002. Alien invasions in aquatic ecosystems: Toward an understanding of brook trout invasions and potential impacts on inland cutthroat trout in western North America. Reviews in Fish Biology and Fisheries, 12: 373-391. DOI:10.1023/A:1025338203702

Dürr, S., Wahl, M. 2004. Isolated and combined impacts of blue mussels (Mytilus edulis) and barnacles (Balanus improvisus) on structure and diversity of a fouling community. Journal of

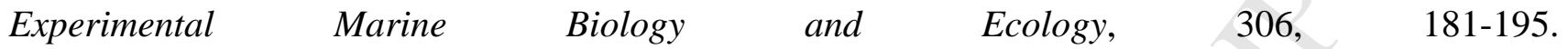
https://doi.org/10.1016/j.jembe.2004.01.006

Eckman, J.E. 1983. Hydrodynamic processes affecting benthic recruitment. Limnology and Oceanography, 28, 241-257. https://10.4319/10.1983.28.2.0241

Eno N.C., Clark R.A., Sanderson W.G. 1997. Non-native marine species in British waters: a review and directory. Joint Nature Conservation Committee, Peterborough, 152 p. http://jncc.defra.gov.uk/pdf/pub02_nonnativereviewdirectory.pdf

Fauvel, P. 1923. Un nouveau serpulien d'eau saumâtre Mercierella N. G. enigmatica N. SP. Bulletin de la Société Zoologique de France, Tome XLVII, 10, 424-430.

Floert, O. 2005. Factors that influence hull fouling on ocean-going vessels. In: Hull fouling as a mechanism for marine invasive species introductions. Godwin, L. S. (Ed.), Bishop Museum Technical Reports, 28, pp 6-13.

Fowler, A.E., Forsström, T., von Numers, M., Vesakoski, O. 2013. The North American mud crab Rhithropanopeus harrisii (Gould, 1841) in newly colonized Northern Baltic Sea: distribution and ecology. Aquatic Invasions, 1, 89-96. http://dx.doi.org/10.3391/ai.2013.8.1.10

Fornos, J.J., Forteza, V., Martinez-Taberner, A. 1997. Modern polychaete reefs in Western Mediterranean lagoons: Ficopomatus enigmaticus (Fauvel) in the Albufera of Menorca, Balearic Islands. Palaeogeography, Palaeoclimatology, Palaeoecology, $\quad 128, \quad$ 175-186. https://doi.org/10.1016/S0031-0182(96)00045-4 
Freire, C.A., Welker, A.F., Storey, J.M., Storey, K.B., Hermes-Lima, M. 2012. Oxidative stress in estuarine and intertidal environments (temperate and tropical). In: Oxidative Stress in Aquatic Ecosystems. Abele, D., Vazquez-Medina, J.P., Zenteno-Savin, T.(Eds.), John Wiley \& Sons, Chichester (UK), pp 41-57. DOI: 10.1002/9781444345988.ch3

Furman, E.R., Yule, A.B. 1990. Self-fertilisation in Balanus improvisus Darwin. Journal of Experimental Marine Biology and Ecology, 144, 235-239.

Garcia-Berthou, E., Boix, D., Clavero, M. 2007. Non-indigenous animal species naturalized in Iberian inland waters. In: Biological invaders in inland waters: profiles, distribution, and threats. Gherardi, F. (Ed.), Springer, Dordrecht (The Netherlands), pp 123-140.

Glasby, T.M., Connell, S.D., Holloway, M.G., Hewitt, C.L. 2007. Nonindigenous biota on artificial structures: could habitat creation facilitate biological invasions? Marine Biology, 151, 887-895. DOI:10.1007/s00227-006-0552-5

INPN (Inventaire National du Patrimoine Naturel). 2018a. Ficopomatus enigmaticus (Fauvel, 1923). https://inpn.mnhn.fr/espece/cd_nom/366400/tab/habitats (accessed in June 2018).

INPN (Inventaire National du Patrimoine Naturel). 2018b. Rhithropanopeus harrisii (Gould, 1841). https://inpn.mnhn.fr/espece/cd_nom/17658 (accessed in June 2018).

ISSG (Invasive Species Specialist Group). 2018. Global invasive species database. http://www.iucngisd.org/gisd/ (accessed in June 2018).

Jongman, R.H.G., Ter Braak, C.J.F., van Tongeren, O.F.R. 1995. Data analysis in community and landscape ecology. Cambridge University Press, Cambridge (UK), 324 p.

Joyce, C.B., Vina-Herbon, C., Metcalfe, D.J. 2005. Biotic variation in coastal water bodies in Sussex, England: Implications for saline lagoons. Estuarine, Coastal and Shelf Science, 65, 633-644. https://doi.org/10.1016/j.ecss.2005.07.006

Justic, D., Rabalais, N.N. \& Turner, R.E. 1995. Stoichiometric nutrient balance and origin of coastal eutrophication. Marine Pollution Bulletin, 30, 41-46. 
Kennedy, V.S. 2011. The invasive dark falsemussel Mytilopsis leucophaeata (Bivalvia: Dreissenidae): a literature review. Aquatic Ecology, 45, 163-183. DOI: 10.1007/s10452-010-9344-6

Luppi, T.A., Spivak, E.D., Anger, K. Valero J.L. 2002. Patterns and Processes of Chasmagnathus granulate and Cyrtograpsus angulatus (Brachyura: Grapsidae) recruitment in Mar Chiquita Coastal Lagoon, Argentina. Estuarine, Coastal and Shelf Science, 55, 287-297. DOI: $\underline{10.1006 / \text { ecss.2001.0904 }}$

McLusky, D.S., Elliott, M. 2004. The estuarine ecosystem: ecology, threats and management. Oxford University Press, Oxford (GB), 214 p. DOI:10.1093/acprof:oso/9780198525080.001.0001

McQuaid, K.A., Griffiths C.L. 2014. Alien reef-building Polychaete drives long-term changes in invertebrate biomass and diversity in a small, urban estuary. Estuarine, Coastal and Shelf Science, 138, 101-106. DOI: 10.1016/j.ecss.2013.12.016

Molnar, J.L., Gamboa, R.L., Revenga, C., Spalding, M.D. 2008. Assessing the global threat of invasive species to marine biodiversity. Frontiers in Ecology and the Environment, 6, 485-492. DOI:10.1890/070064

Morais, G.C., Camargo, M.G., Lana, P. 2016. Intertidal assemblage variation across a subtropical estuarine gradient: How good conceptual and empirical models are? Estuarine, Coastal and Shelf Science, 170, 91-101. https://doi.org/10.1016/j.ecss.2015.12.020

Obenat, S.M., Pezzani, S.E. 1994. Life cycle and population structure of the polychaete Ficopomatus enigmaticus (Serpulidae) in Mar Chiquita Coastal Lagoon, Argentina. Estuaries, 17, 263-270.

Oliva, M., Martinelli, E., Galli, G., Pretti, C. 2017. PDMS-based films containing surface-active amphiphilic block copolymers to combat fouling from barnacles B. amphitrite and B. improvisus. Polymer, 108, 476-482. 
Oliva., M., Mennillo, E., Barbaglia, M., Monni, G., Tardelli, F., Casu, V., Pretti, C. 2018. The serpulid Ficopomatus enigmaticus (Fauvel, 1923) as candidate organisms for ecotoxicological assays in brackish and marine waters. Ecotoxicology and Environmental Safety, 148, 1096-1103. https://doi.org/10.1016/j.ecoenv.2015.10.006

Pérez-Ruzafa, A., Fernández, A.I., Marcos, C., Gilabert, J., Quispe, J.I., García-Charton, J.A. 2005. Spatial and temporal variations of hydrological conditions, nutrients and chlorophyll a in a Mediterranean coastal lagoon (Mar Menor, Spain). Hydrobiologia, 55, 11-27.

Rajagopal, S., Van der Gaag, M., Van der Velde, G., Jenner, H.A. 2005. Upper temperature tolerances of exotic brackish-water mussel, Mytilopsis leucophaeata (Conrad): An experimental study. Marine Environmental Research, 60, 512-530. doi:10.1016/j.marenvres.2005.02.002

Saudray Y. 1956. Un crustacé décapode nouveau pour le canal de Caen à la mer : Heteropanope tridentatus Maitland. Bulletin de la Société Linnéenne de Normandie, 8, 61-62.

Seebens, H., Gastner, M.T., Blasius, B. 2013. The risk of marine bioinvasion caused by global shipping. Ecological Letters, 16 (6), 782-790. DOI: 10.1111/ele.12111

Straughan, D. 1972. Ecological studies of Mercierella enigmatica Fauvel (Annelida, Polychaeta) in the Brisbane River. Journal of Animal Ecology, 41, 93-136.

Swindt, E., Iribane, O., Isla, F.I. 2004. Physical effects of an invading reef-building polychate on an Argentinean estuarine environment. Estuarine, Coastal and Shelf Science, 59, 109-120. https://doi.org/10.1016/j.ecss.2003.06.004

ten Hove, H.A., Weerdenburg, J.C.A. 1978. A generic revision of the brackish-water serpulid Ficopomatus Southern 1921 (Polychaeta: Serpulidae), including Mercierella Fauvel 1923, Sphaeropomatus Treadwell 1934, Mercierellopsis Rioja 1954, and Neopomatus Pillai 1960. Biological Bulletin, 154, 96-120. 
Verween, A., Vincx, M., Degraer, S. 2010. Mytilopsis leucophaeata: The brackish water equivalent of Dreissena polymorpha? A review. In: The Zebra Mussel in Europe. van der Velde, G., Rajagopal, S., bij de Vaate, A. (Eds.), Backhuys Publishers, Leiden (The Netherlands), pp. 29-44.

Zaiko, A., Olenin, S., Daunys, D., Nalepa, T. 2007. Vulnerability of benthic habitats to the aquatic invasive species. Biological Invasions, 9, 703-714. DOI:10.1007/s10530-006-9070-0

Zhulidov, A.V., Kozhara, A.V., van der Velde G., Leuven, R.S.E.W., Zhulidov, D.A., Gurtovaya, T.Y., Nalepa, T.F., Santiago-Fandino, V.J.R. 2015. New records from the Ponto-Azov region demonstrate the invasive potential of Mytilopsis leucophaeata (Conrad, 1831) (Bivalvia: Dreissenidae). Journal of Molluscan Studies, 81, 412-416. https://doi.org/10.1093/mollus/eyv005

Zukowski, S. Walker, K.F. 2009. Freshwater snails in competition: alien Physa acuta (Physidae) and native Glyptophysa gibbosa (Planorbidae) in the River Murray, South Australia. Marine and Freshwater Research, 60, 999-1005. DOI: 10.1071/MF08183 
Table 1. Location and main features of the marinas explored in Normandy for biofouling collection. Marina capacity is expressed in number of mooring berths. Sources: personal communications from harbor masters and http://www.portbooker.com/en/moorings/france/lower-normandy/. Mean values $\left( \pm\right.$ SEM) of water salinity recorded during the exploration period over 2 weeks in January $2015\left(1^{\text {st }}\right.$ measurements), and on the $8^{\text {th }}$ and $9^{\text {th }}$ March $2015\left(2^{\text {nd }}\right.$ measurements $)(n=3)$. Mean values $( \pm$ SEM) of water $\mathrm{pH}$ was calculated only during the second period of measurements.

\begin{tabular}{|c|c|c|c|c|c|c|}
\hline $\begin{array}{l}\text { City (number of } \\
\text { residents) }\end{array}$ & Basin name & $\begin{array}{l}\text { Geographic } \\
\text { coordinates }\end{array}$ & Capacity & $\begin{array}{c}\text { Marina structures / main source } \\
\text { of freshwaters }\end{array}$ & $\begin{array}{l}\text { Salinity (PSU): } 1^{\text {st }} \text { record / } \\
2^{\text {nd }} \text { record }\end{array}$ & $\mathrm{pH}$ \\
\hline $\begin{array}{l}\text { Cherbourg } \\
(25,337)\end{array}$ & $\begin{array}{l}\text { CHOP } \\
\text { Outer-port } \\
\mathrm{CHCH} \\
\text { Chantereyne }\end{array}$ & $\begin{array}{c}49^{\circ} 38.2660^{\prime} \mathrm{N} \\
1^{\circ} 37.1220^{\prime} \mathrm{W} \\
49^{\circ} 38.8542^{\prime} \mathrm{N} \\
1^{\circ} 37.1621^{\prime} \mathrm{W}\end{array}$ & 1556 & $\begin{array}{l}\text { Floating pontoons / The River } \\
\text { La Divette } \\
\text { Floating pontoons / The River } \\
\text { La Divette }\end{array}$ & $\begin{array}{l}17.72 \pm 0.37 / 14.99 \pm 0.57 \\
26.40 \pm 0.36 / 30.03 \pm 0.32\end{array}$ & $\begin{array}{l}7.91 \pm 0.05 \\
7.94 \pm 0.01\end{array}$ \\
\hline $\begin{array}{l}\text { Saint-Vaast-la- } \\
\text { Hougue }(2,128)\end{array}$ & $\begin{array}{l}\text { SVH } \\
\text { Marina }\end{array}$ & $\begin{array}{l}49^{\circ} 35.1898^{\prime} \mathrm{N} \\
1^{\circ} 15.7477^{\prime} \mathrm{W}\end{array}$ & 750 & $\begin{array}{l}\text { Floating pontoons / no } \\
\text { freshwater inflows }\end{array}$ & $32.57 \pm 0.27 / 32.40 \pm 0.06$ & $7.91 \pm 0.01$ \\
\hline Carentan $(6,371)$ & $\begin{array}{l}\text { CAR } \\
\text { Marina }\end{array}$ & $\begin{array}{l}49^{\circ} 18.6345^{\prime} \mathrm{N} \\
1^{\circ} 14.1036^{\prime} \mathrm{W}\end{array}$ & 310 & $\begin{array}{l}\text { Floating pontoons / The Rivers } \\
\text { La Douve and La Taute }\end{array}$ & $9.98 \pm 0.01 / 4.57 \pm 0.12$ & $8.05 \pm 0.04$ \\
\hline $\begin{array}{l}\text { Courseulles-sur- } \\
\text { Mer }(3,892)\end{array}$ & $\begin{array}{l}\text { CIPB } \\
\text { Ile de Plaisance } \\
\text { CJB } \\
\text { Joinville basin }\end{array}$ & $\begin{array}{l}49^{\circ} 20.0762^{\prime} \mathrm{N} \\
0^{\circ} 27.6675^{\prime} \mathrm{W} \\
49^{\circ} 19.5790^{\prime} \mathrm{N} \\
0^{\circ} 27.470^{\prime} \mathrm{W}\end{array}$ & 258 & $\begin{array}{l}\text { Floating pontoons / The River } \\
\text { La Seulles } \\
\text { Floating pontoons / The River } \\
\text { La Seulles }\end{array}$ & $20.64 \pm 0.53 / 28.53 \pm 0.26$ & $7.89 \pm 0.01$ \\
\hline Caen $(114,007)$ & $\begin{array}{l}\text { CAE } \\
\text { Saint Pierre }\end{array}$ & $\begin{array}{l}49^{\circ} 10.9510^{\prime} \mathrm{N} \\
0^{\circ} 21.1903^{\prime} \mathrm{W}\end{array}$ & 92 & $\begin{array}{l}\text { Floating pontoons / The River } \\
\text { Odon }\end{array}$ & $1.90 \pm 0.69 / 0.13 \pm 0.01$ & $7.89 \pm 0.02$ \\
\hline $\begin{array}{l}\text { Ouistreham } \\
(8,674)\end{array}$ & $\begin{array}{l}\text { OUI } \\
\text { Marina }\end{array}$ & $\begin{array}{l}49^{\circ} 16.5689^{\prime} \mathrm{N} \\
0^{\circ} 14.9217^{\prime} \mathrm{W}\end{array}$ & 650 & $\begin{array}{l}\text { Fixed pontoons / Canal from } \\
\text { Caen to the Sea (The River } \\
\text { Odon) }\end{array}$ & $7.88 \pm 0.03 / 5.00 \pm 0.02$ & $7.90 \pm 0.03$ \\
\hline Cabourg $(3,523)$ & $\begin{array}{l}\text { CAB } \\
\text { Port Guillaume }\end{array}$ & $\begin{array}{c}49^{\circ} 17.6657^{\prime} \mathrm{N} \\
0^{\circ} 5.6867^{\prime} \mathrm{W} \\
\end{array}$ & 600 & $\begin{array}{l}\text { Floating pontoons / The River } \\
\text { La Dives }\end{array}$ & $28.10 \pm 0.53 / 18.18 \pm 0.03$ & $7.80 \pm 0.01$ \\
\hline Deauville $(4,371)$ & $\begin{array}{l}\text { DMOB } \\
\text { Morny } \\
\text { DMB } \\
\text { Marina } \\
\end{array}$ & $\begin{array}{c}49^{\circ} 21.8526^{\prime} \mathrm{N} \\
0^{\circ} 4.7546^{\prime} \mathrm{E} \\
49^{\circ} 22.0001^{\prime} \mathrm{N} \\
0^{\circ} 4.2293^{\prime} \mathrm{E}\end{array}$ & 360 & $\begin{array}{l}\text { Floating pontoons / The River } \\
\text { La Touques } \\
\text { Floating pontoons / The River } \\
\text { La Touques }\end{array}$ & $15.39 \pm 0.42 / 21.38 \pm 0.51$ & $7.85 \pm 0.00$ \\
\hline Honfleur $(8,175)$ & $\begin{array}{l}\text { HON } \\
\text { Old basin }\end{array}$ & $\begin{array}{c}49^{\circ} 25.2432^{\prime} \mathrm{N} \\
0^{\circ} 14.0307^{\prime} \mathrm{E}\end{array}$ & 90 & $\begin{array}{l}\text { Floating pontoons / The Rivers } \\
\text { La Claire and Le Mordouet }\end{array}$ & $0.96 \pm 0.11 / 3.62 \pm 0.08$ & $7.89 \pm 0.02$ \\
\hline
\end{tabular}


Table 2. Presence ( $F$. enigmaticus) or density (ind. $\mathrm{m}^{-2}$ ) of attached or motile species associated with tubeworm reefs in 6 marinas populated by Ficopomatus enigmaticus and located in Normandy (France) (for site abbreviations, see Tab. 1). Species status as native vs alien (or cryptogenic) are mentioned according to Dewarumez et al. (2011) and the databases from the Invasive Species Specialist Group (ISSG; http://www.iucngisd.org/gisd/) and Delivering Alien Invasive Species Inventories for Europe (DAISIE; http://www.europe-aliens.org/). Frequency in \% (Freq.) and mean density (Dens.) ( \pm $\mathrm{SEM})$ are indicated for taxa. Density (ind. $\mathrm{m}^{-2}$ ), species richness, Shannon diversity index $\left(\mathrm{H}^{\prime}\right)$ and equitability (E) are indicated for groups of attached species or motile species and for all (attached + motile) species in each marina.

\begin{tabular}{|c|c|c|c|c|c|c|c|c|c|c|}
\hline & & Species status in France & CAR & CJB & CIPB & CAE & OUI & HON & Freq. & Mean Dens. \\
\hline \multirow{9}{*}{ 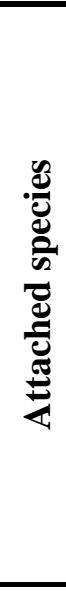 } & $\begin{array}{l}\text { Ficopomatus (Mercierella) } \\
\text { enigmaticus }\end{array}$ & $\begin{array}{l}\text { Alien (Australia, Indian } \\
\text { Oceen, West Pacific) }\end{array}$ & $\mathrm{X}$ & $\mathrm{X}$ & $\mathrm{X}$ & $\mathrm{X}$ & $\mathrm{X}$ & $\mathrm{X}$ & 100,00 & \\
\hline & B. improvisus & $\begin{array}{l}\text { Alien (American Atlantic } \\
\text { coasts? Cryptogenic?) }\end{array}$ & 133.33 & & & $3,646.67$ & $10,046.67$ & 520.00 & 66,67 & $3,586.67 \pm 2,292.47$ \\
\hline & M. leucophaeata & Alien (Gulf of Mexico) & $3,116.67$ & & & $1,651.67$ & $1,668.33$ & & 50,00 & $2,145.56 \pm 485.58$ \\
\hline & Mya arenaria & Alien (North-west Atlantic) & 41.67 & & 20 & 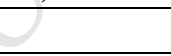 & & & 16,67 & 26.67 \\
\hline & Molgula sp. & $?$ & & 66.67 & 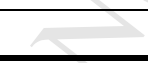 & & & & 16,67 & 66.67 \\
\hline & Species richness & & $3(+1)$ & $1(+1)$ & $0(+1)$ & $2(+1)$ & $2(+1)$ & $1(+1)$ & & \\
\hline & Density (ind. $\mathrm{m}^{-2}$ ) & & $3,291.67$ & 66.67 & 0.00 & $5,298.33$ & $11,715.00$ & 520.00 & & \\
\hline & $\mathrm{H}^{\prime}$ & & 0.34 & 0 & 0 & 0.90 & 0.59 & 0 & & \\
\hline & $\mathrm{E}$ & & 0.21 & ) & & 0.90 & 0.59 & & & \\
\hline \multirow{14}{*}{ 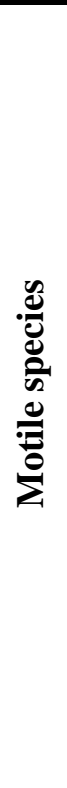 } & Alitta (Neanthes) succinea & Native & 111.67 & 1.67 & & & 3.33 & 68.33 & 66,67 & $46.25 \pm 26.77$ \\
\hline & Nereis zonata & Native & 23.33 & 3.33 & 3.33 & & 3.33 & 23.33 & 83,33 & $11.33 \pm 4.90$ \\
\hline & Physella (Physa) acuta & $\begin{array}{l}\text { Alien (North America)? } \\
\text { Cryptogenic? }\end{array}$ & 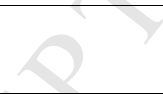 & & & 1.67 & & & 16,67 & 1.67 \\
\hline & Gammarus zaddachi & Native & 106.67 & 20.00 & 60.00 & 15.00 & 36.67 & & 83,33 & $47.67 \pm 16.71$ \\
\hline & Melita palmata & Native & 143.33 & 33.33 & 3.33 & & 360.00 & & 66,67 & $135.00 \pm 80.81$ \\
\hline & Monocorophium sextonae & $\begin{array}{l}\text { Alien (New-Zealand)? } \\
\text { Cryptogenic? }\end{array}$ & & & & 61.67 & & & 16,67 & 61.67 \\
\hline & Leptocheirus tricristatus & Native & & & & 261.67 & & & 16,67 & 261.67 \\
\hline & Lekanesphaera hookeri & Native & 360.00 & 3.33 & 3.33 & & 33.33 & & 66,67 & $100.00 \pm 86.95$ \\
\hline & Idotea neglecta & Native & & & 1.67 & & & & 16,67 & 1.67 \\
\hline & Palaemon elegans & Native & & 11.67 & 18.33 & & & & 33,33 & $15.00 \pm 3.33$ \\
\hline & Palaemonetes varians & Native & & 25.00 & 23.33 & & & & 33,33 & $24.17 \pm 0.83$ \\
\hline & Rhithropanopeus harrisi & $\begin{array}{l}\text { Alien (the Atlantic coast of } \\
\text { North America) }\end{array}$ & 43.33 & 8.33 & 8.33 & & $1,076.67$ & 571.67 & 83,33 & $341.67 \pm 212.64$ \\
\hline & Carcinus maenas & Native & & 20.00 & 8.33 & & 18.33 & & 50,00 & $15.56 \pm 3.64$ \\
\hline & Chironomidae Orthocladiinae & $?$ & & & & 31.67 & & & 16,67 & 31.67 \\
\hline
\end{tabular}




\begin{tabular}{|c|c|c|c|c|c|c|c|c|c|}
\hline & $\begin{array}{l}\text { Chironomidae Chironominae } \\
\operatorname{Tr} \text { Chironomini }\end{array}$ & & & & & & 1.67 & 16,67 & 1.67 \\
\hline & Species richness & 6 & 9 & 9 & 4 & 7 & 4 & & \\
\hline & Density (ind. $\mathrm{m}^{-2}$ ) & 788.33 & 126.67 & 130.00 & 371.67 & $1,531.67$ & 668.00 & & \\
\hline & $\mathrm{H}^{\prime}$ & 2.13 & 2.74 & 2.35 & 1.31 & 1.21 & 0.72 & & \\
\hline & E & 0.83 & 0.87 & 0.74 & 0.56 & 0.43 & 0.45 & & \\
\hline \multirow{4}{*}{ 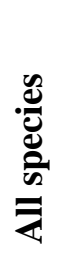 } & Total species richness & 10 & 11 & 10 & 8 & 10 & 6 & & \\
\hline & Total density (ind. $\mathrm{m}^{-2}$ ) & $4,080.00$ & 193.33 & 130.00 & $5,670.00$ & $13,246.67$ & $1,185.00$ & & \\
\hline & $\mathrm{H}^{\prime}$ & 1.40 & 2.73 & 2.35 & 1.27 & 1.18 & 1.39 & & \\
\hline & $\mathrm{E}$ & 0.44 & 0.82 & 0.74 & 0.45 & 0.37 & 0.60 & & \\
\hline
\end{tabular}


Table 3. Sørensen similarity indices $\left(\mathrm{S}_{\mathrm{or}}\right)$ calculated for pairs of marinas by considering the presence of 1) all invertebrate species (including both attached and motile species) (numbers in italics) and 2) only attached species associated to biofouling reefs (numbers in bold).

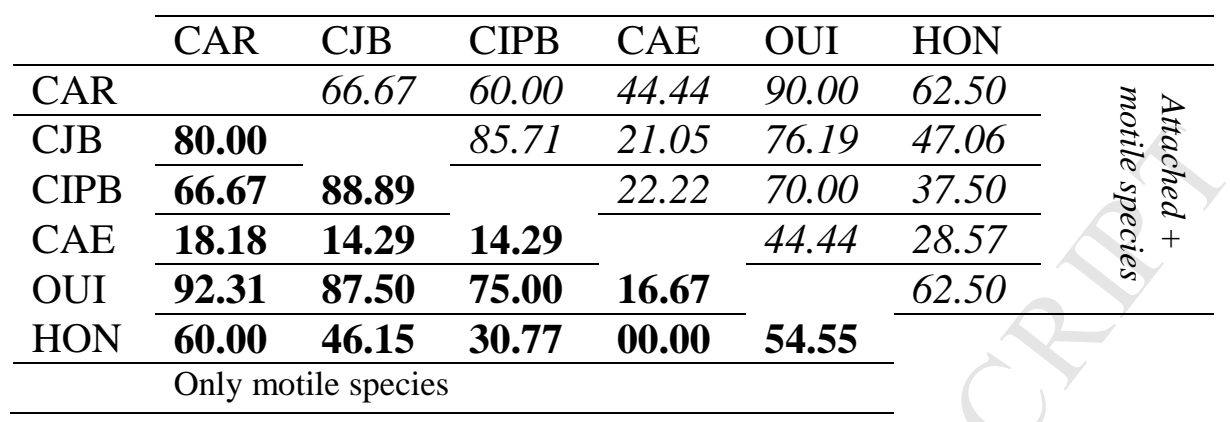




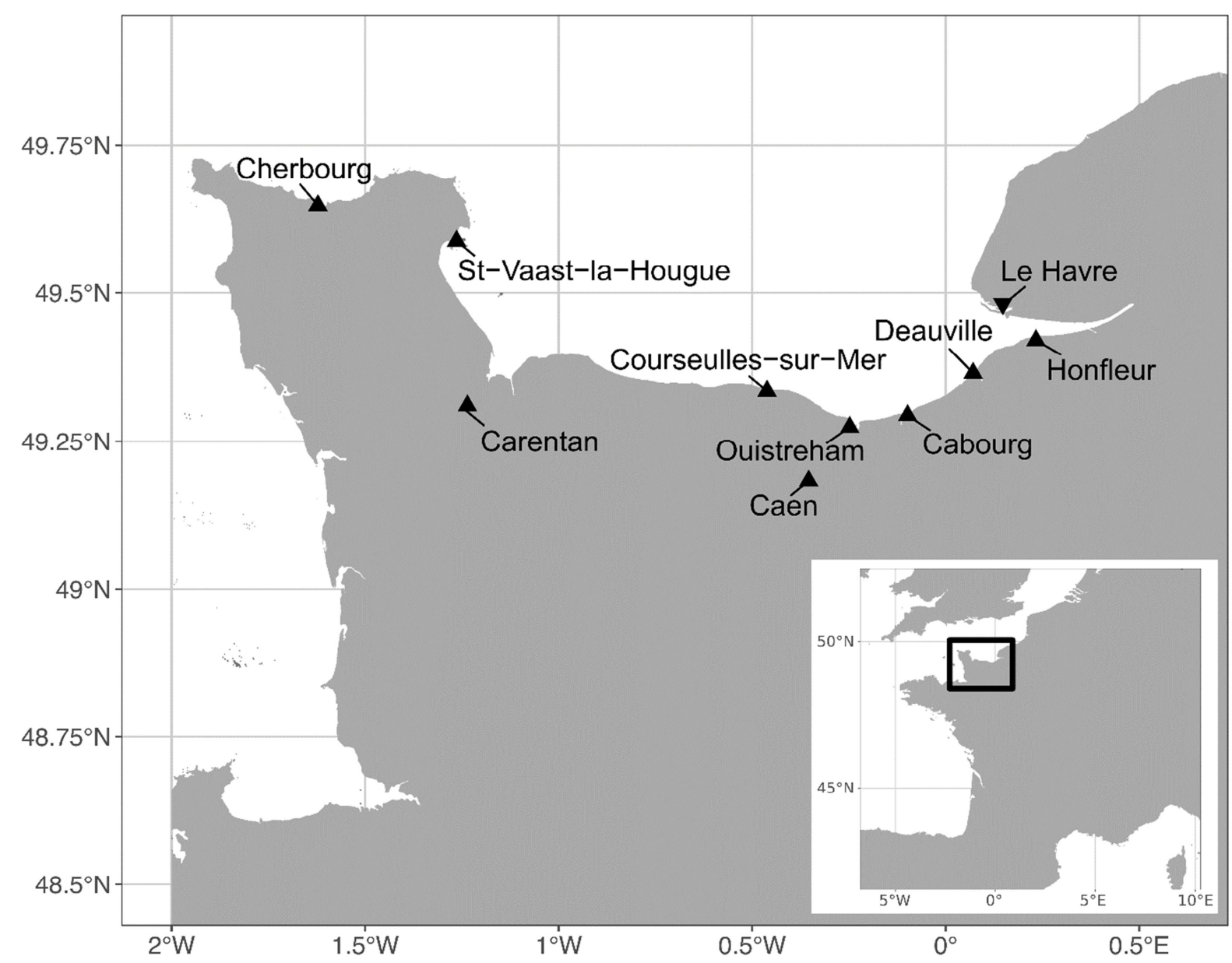

Fig. 1. Maps of the sampling region. Le Havre, the main harbour in region, is indicated in italics, in addition to all sampling sites: Cherbourg (2 marinas: $\mathrm{CHOP}$ and $\mathrm{CHCH}$ ), SaintVaast-la-Hougue (SVH), Carentan (CAR), Courseulles-sur-Mer (2 marinas: CIPB and CJB), Caen (CAE), Ouistreham (OUI), Cabourg (CAB), Deauville (2 marinas: DMOB and DMB), Honfleur (HON). For marina abbreviations, see Table 1. 

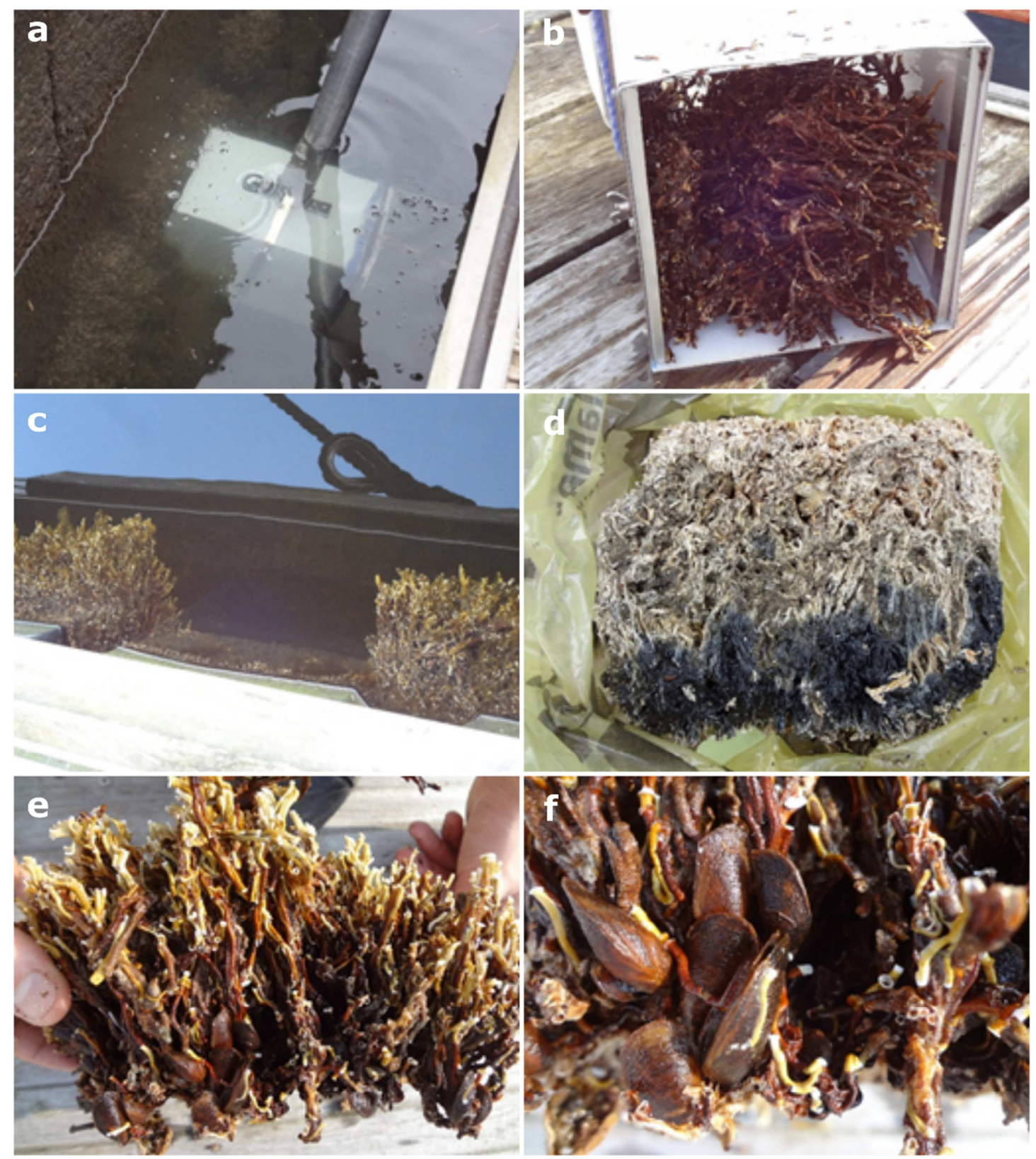

Fig. 2. Sampling of Ficopomatus enigmaticus reefs on marina structures (a, b, c), with examples of $F$. enigmaticus reefs displaying a black layer due to reducing conditions (Honfleur marina; d) or the presence of mussels Mytilopsis leucophaeata attached to the reefs' base (Carentan marina; e, f). 

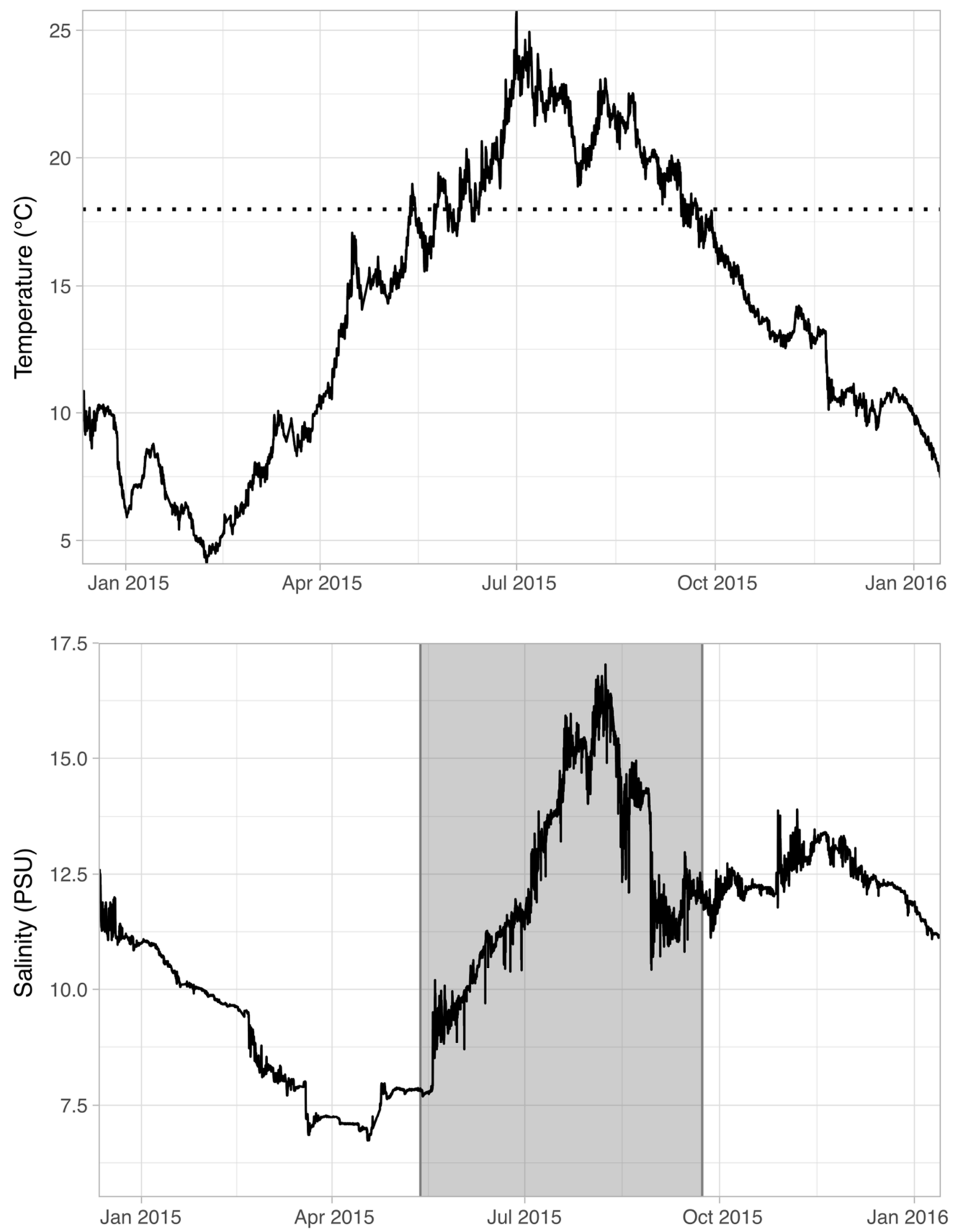

Fig. 3. High-frequency $(20 \mathrm{~min})$ measurements of water temperature and salinity in the marina of Carentan (CAR) throughout the sampling year (2015). The dotted line indicates the threshold of minimum temperature required for the spawning of $F$. enigmaticus $\left(18^{\circ} \mathrm{C}\right)$. The shaded area shows the period of potential spawning and recruitment on top of salinity levels. 


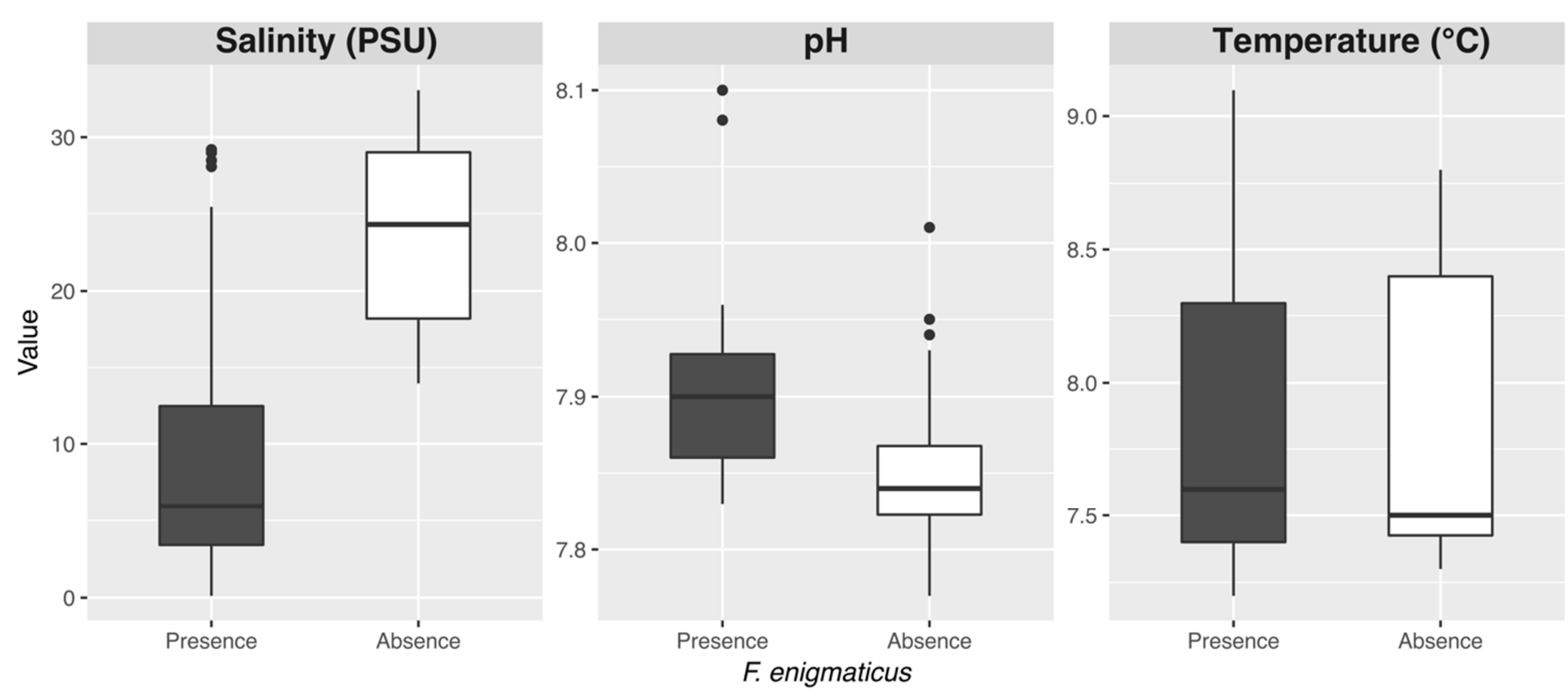

Fig. 4. Environmental conditions (salinity, $\mathrm{pH}$, water temperature) in marinas with and without Ficopomatus enigmaticus. The lower and upper notches represent the $1^{\text {st }}$ and $3^{\text {rd }}$ quartiles, the lower and upper whiskers the $95 \%$ confidence interval. Dots indicate points outlying the $95 \%$ confidence interval. 


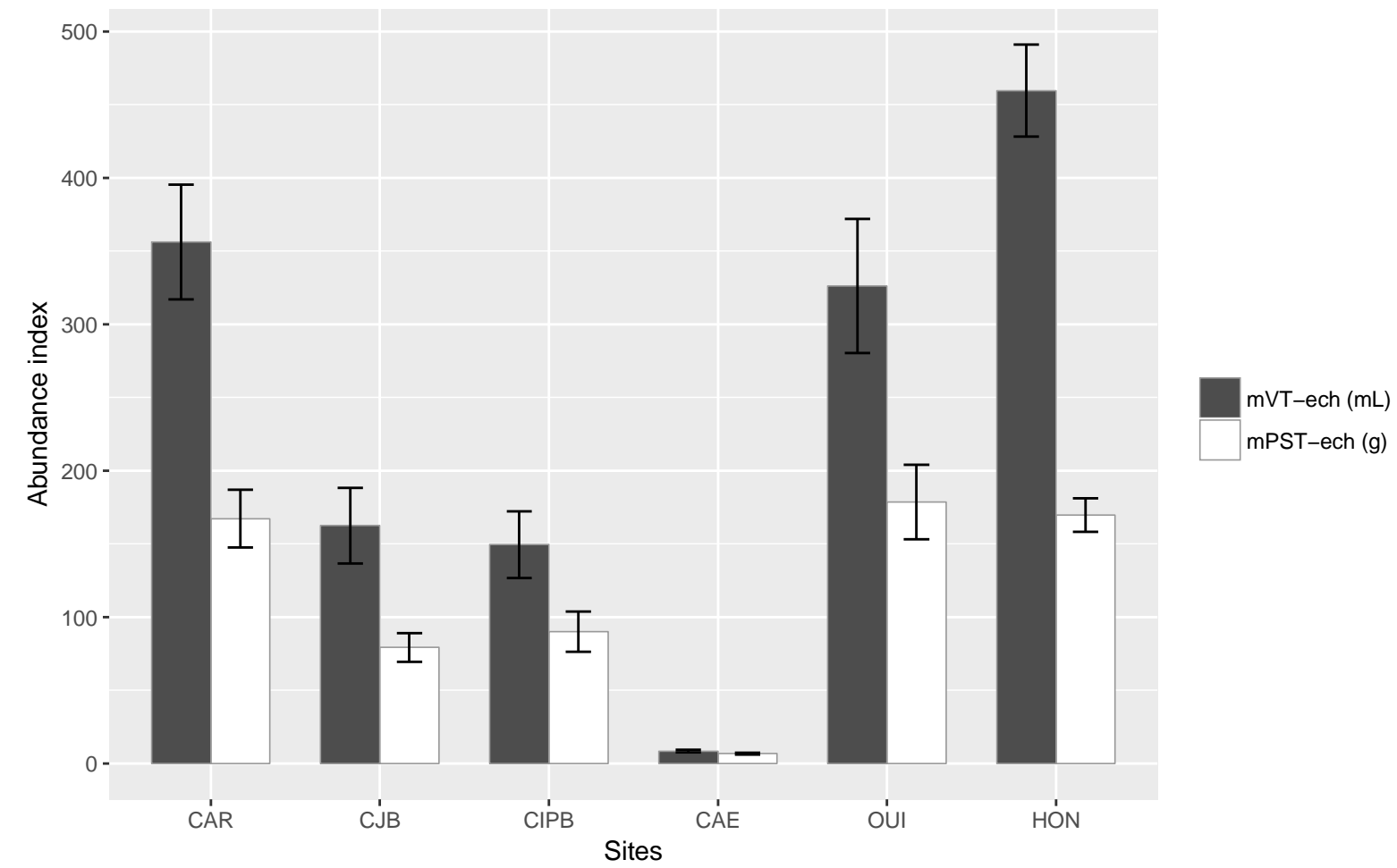

Fig. 5. Abundance indices (mean \pm SEM) expressed in biovolume $\left(\mathrm{mL} 0.04 \mathrm{~m}^{-2}\right)$ and dry weight $\left(\mathrm{g} 0.04 \mathrm{~m}^{-2}\right)$ of Ficopomatus enigmaticus and associated sessile species at sampling sites with $F$. enigmaticus. CAR: Carentan marina; CIBP: Ile de Plaisance Basin and CJB: Joinville basin, both in Courseulles; CAE: Saint Pierre basin in Caen; OUI: Ouistreham marina; HON: old basin in Honfleur. 


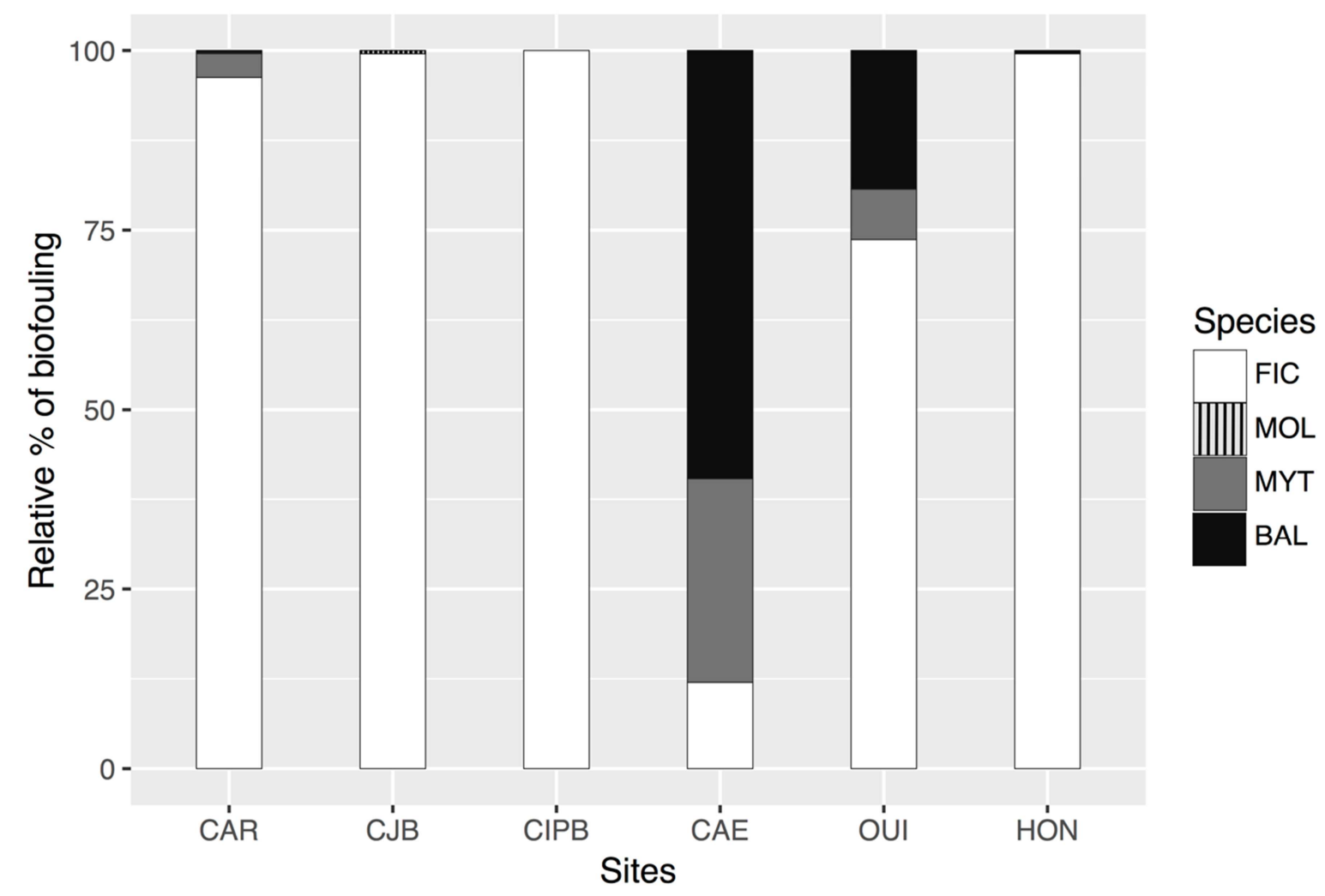

Fig. 6. Proportion (\%) of total biovolume of biofouling formed by each sessile species found at sites with $F$. enigmaticus (FIC): Molgula sp (MOL); Mytilopsis leucophaeata (MYT) and Balanus improvisus (BAL). Mya arenaria has been included in the analyses but was omitted in the legend due to its undiscernible contribution to the biofouling $(<0.5 \%$, in CAR only). CAR: Carentan marina; CIBP: Ile de Plaisance Basin and CJB: Joinville basin, both in Courseulles; CAE: Saint Pierre basin in Caen; OUI: Ouistreham marina; HON: old basin in Honfleur. 

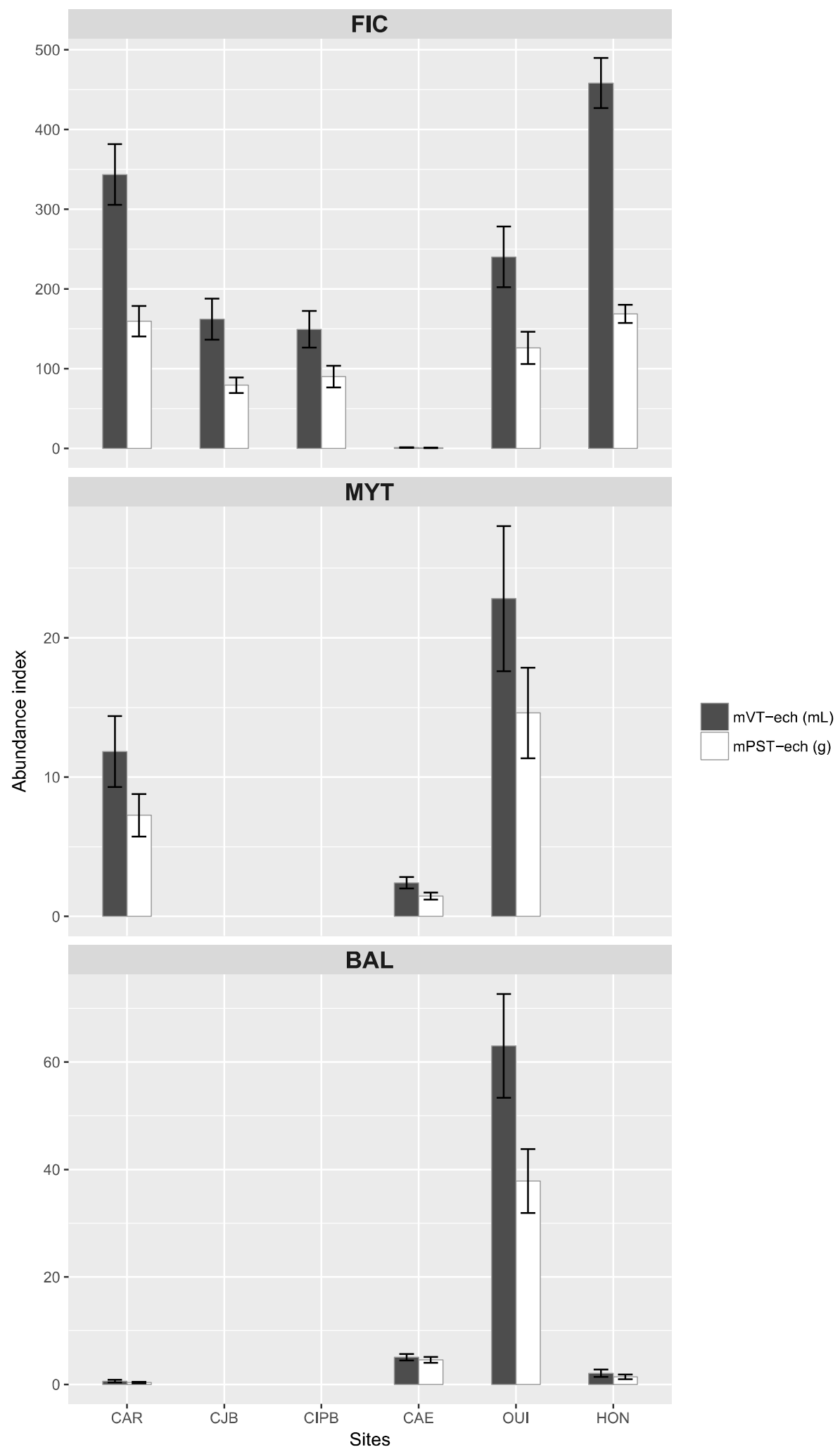

Fig. 7. Mean abundance (biovolume and dry weight) and standard error of the mean (whiskers) of Ficopomatus enigmaticus (FIC), Mytilopsis leucophaeata (MYT) and Balanus improvisus (BAL) at sites colonized by these species. CAR: Carentan marina; CIBP: Ile de Plaisance Basin and CJB: Joinville basin, both in Courseulles; CAE: Saint Pierre basin in Caen; OUI: Ouistreham marina; HON: old basin in Honfleur. 


\section{ACCEPTED MANUSCRIPT}
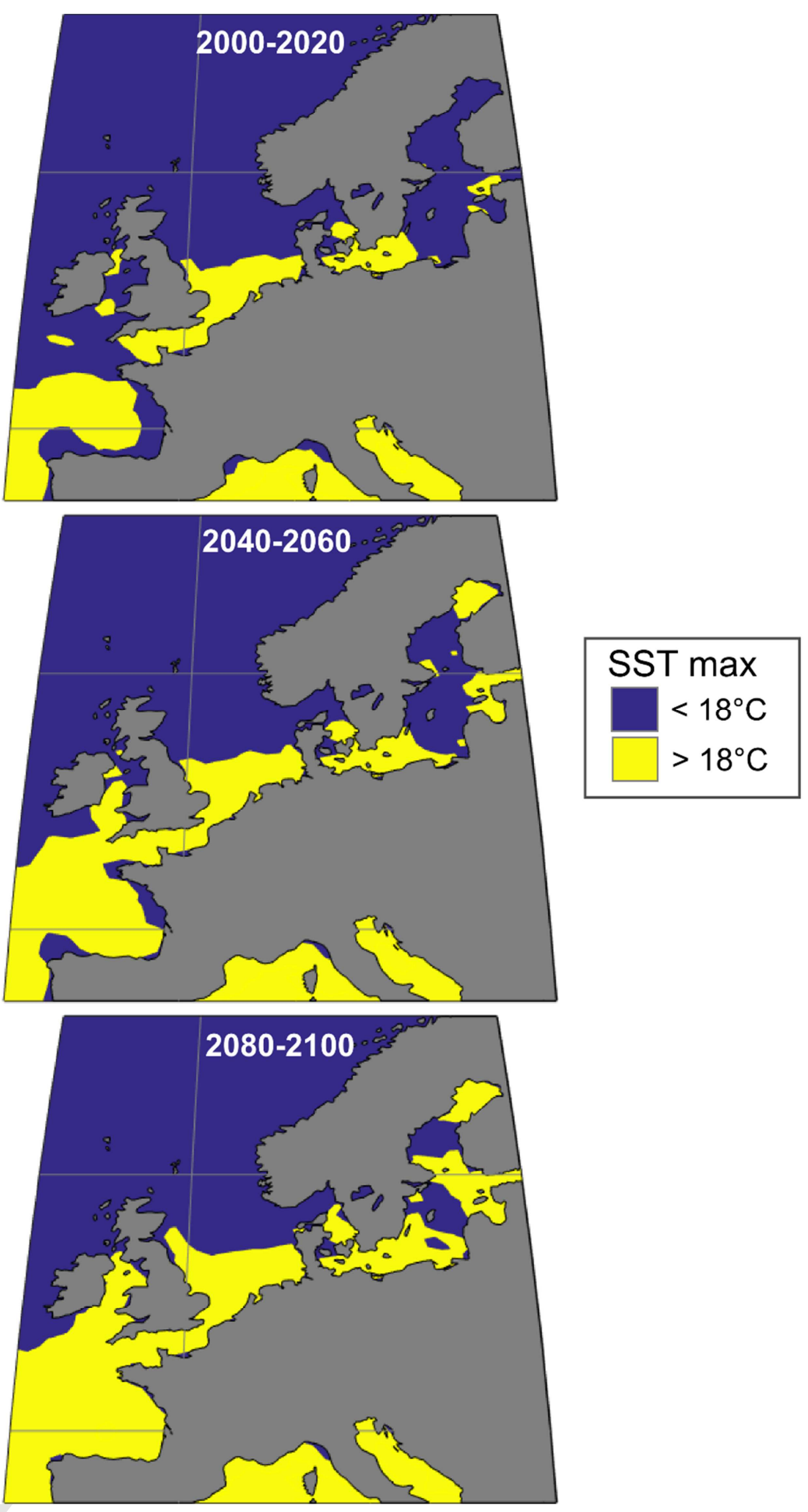

Fig. 8. Projections of future sea surface temperature (SST) reaching $\geq 18^{\circ} \mathrm{C}$, the minimum temperature for the spawning of $F$. enigmaticus, in northern Europe over the course of three periods (2000-2020, 2040-2060 and 2080-2100). The sea surface temperature data were obtained from outputs of the CMIP5 model (Coupled Model Intercomparison Project Phase 5; World Climate Research Program) based on the RCP8.5 scenario (available at: https://esgfnode.llnl.gov/search/cmip5/). 